\title{
Reflexiones de los autores y las editoras sobre el debate
}

Ezequiel Adamovsky, Sergio Caggiano, Nicolás Fernández Bravo, María de Lourdes Ghidoli, María Cecilia Martino, Eva Lamborghini and Lea Geler

\section{(2) OpenEdition}

Journals

\section{Electronic version}

URL: http://journals.openedition.org/corpusarchivos/1748

DOI: 10.4000/corpusarchivos. 1748

ISSN: $1853-8037$

\section{Publisher}

Diego Escolar

\section{Electronic reference}

Ezequiel Adamovsky, Sergio Caggiano, Nicolás Fernández Bravo, María de Lourdes Ghidoli, María Cecilia Martino, Eva Lamborghini y Lea Geler, «Reflexiones de los autores y las editoras sobre el debate », Corpus [En línea], Vol 6, No 2 | 2016, Publicado el 02 enero 2017, consultado el 30 abril 2019. URL : http://journals.openedition.org/corpusarchivos/1748; DOI : 10.4000/corpusarchivos. 1748

This text was automatically generated on 30 April 2019. 


\title{
Reflexiones de los autores y las editoras sobre el debate
}

\author{
Ezequiel Adamovsky, Sergio Caggiano, Nicolás Fernández Bravo, María \\ de Lourdes Ghidoli, María Cecilia Martino, Eva Lamborghini and Lea \\ Geler
}

\section{Comentario de Ezequiel Adamovsky}

1 Es un gran acierto de los editores de Corpus el haber promovido un debate sobre lo "negro", y de las coordinadoras del dossier y del debate por proponer uno en torno a los regímenes de clasificación racial en Argentina en su plano específicamente visual. Pues es allí donde en última instancia se juega -mucho más que en el plano del lenguaje verbalsu solidez y su efectividad. La lectura de los trabajos de los colegas me ha resultado enormemente estimulante. A partir de ella, quisiera proponer una serie de preguntas que quizás ayuden a continuar con un diálogo colectivo.

2 1.- El eje central de los trabajos de los colegas, entiendo, pasa por el análisis de los mecanismos de invisibilización o deshumanización de los afroargentinos en el imaginario nacional (o sobre sus estrategias de revisibilización en el pasado reciente). En ese marco, puede que el mío desentone, ya que mis investigaciones no se enfocan en esa comunidad en particular, sino en la pregunta por los modos en los que las diferencias de color de piel afectan las identidades de clase en la Argentina (particularmente entre los argentinos que no imaginan pertenecer a ningún grupo étnico en particular). En ese marco, mi trabajo apunta a mostrar que, al menos en ciertos tipos de producción cultural -como en este caso el criollismo- hubo espacio para tematizar la diversidad de los colores de la nación y para dar visibilidad a lo mestizo e incluso a lo afroargentino.

3 Ambos énfasis no son sin embargo contrarios. Todos partimos del reconocimiento de que las imágenes de la nación -al menos las oficiales- se afirman en la idea de que el pueblo argentino es blanco-europeo y, por ello, producen un borramiento de lo no-blanco. En mi caso, el eje está puesto en mostrar que las imágenes oficiales no tienen un dominio total 
sobre la cultura argentina, sino que entran en disputa con visiones disidentes pero muy poderosas, que han sido capaces de reponer aquello que las primeras pretenden omitir. Puede, en fin, que convenga matizar la idea de una hegemonía fuerte en el plano de los regímenes de clasificación racial, para abrir la posibilidad de pensar que lo que hubiera fuera en realidad una pretensión de dominancia disputada (especialmente en el terreno visual). Mi trabajo lo muestra en el terreno de las representaciones de lo criollo, pero habiendo ya avanzado en otros campos tengo la impresión de que en la cultura de masas y en la prensa de los años veinte, treinta, cuarenta y posteriores, aparecen afroargentinos en una proporción relevante y no siempre como parte de cuadros grotescos o deshumanizadores (aunque por supuesto éstos también están bien presentes, en eso coincido plenamente con el trabajo de María de Lourdes Ghidoli).

2.- Cuando relata el reemplazo del rótulo "negro" por el de "afroamericano" en los clasificadores del AGN, Sergio Caggiano aporta una interesantísima dimensión que podría ser un puente para el diálogo de todos los trabajos. Porque hay un deslizamiento que se produce entre ambos términos ("negro" alude al conjunto principalmente a partir de un rasgo fenotípico, mientras que "afrodescendiente" apunta prioritariamente al linaje). En un país como Estados Unidos, donde el régimen racial se organizó fundamentalmente a partir del linaje, el segundo término puede intercambiarse con el primero sin consecuencias semánticas decisivas: de acuerdo a la one-drop rule, cualquier afrodescendiente está por definición excluido de la raza "blanca". Pero no es así como han funcionado las categorías raciales en la Argentina contemporánea. En nuestro régimen racial, una persona es "blanca" si luce "blanca", y poco importa si hubo por allí algún abuelo "negro". En otras palabras, se puede ser afrodescendiente y blanco al mismo tiempo. A esto habría que sumar el hecho, hace tiempo señalado por Alejandro Frigerio, de que en terreno estrictamente visual, el ojo argentino sólo está entrenado para captar rasgos "negros" allí donde son notoriamente prominentes y estereotípicos. Personas que son de aspecto obviamente "afrodescendiente" a ojos de un norteamericano, sencillamente son percibidas como "blancos" por un argentino (ejemplo clásico: Horacio Salgán). Y ya que todo indica que hubo una intensa exogamia entre los afroargentinos, es perfectamente esperable que su presencia demográfica pase en buena medida visualmente inadvertida en la vía pública y en las interacciones cotidianas. La pregunta inevitable sería entonces: ¿Qué sería un "afroargentino" en términos estrictamente visuales?

5 La respuesta a esa pregunta tiene consecuencias prácticas concretas para la investigación. En mi caso, trabajo con fotografías de prensa gráfica desde hace años, poniendo especial atención a la presencia de marcaciones no-blancas. En la enorme mayoría de los casos, con reproducciones en blanco y negro, me resulta sencillamente imposible constatar si hay o no afroargentinos. Por ello, doy por "probados" únicamente casos indiscutibles, que no son otros que los que muestran rasgos estereotípicos y muy pronunciados. No tengo dudas de que omito muchos casos de los que no hay modo de estar seguros, con lo que seguramente mi propio trabajo contribuye a reforzar un régimen de visibilidad determinado. Dicho de otro modo: es posible que los afroargentinos sí estén allí presentes por todas partes en las fotos de todas las épocas: así como no los vemos en la vía pública, tampoco notaríamos su presencia en las fotos o las ilustraciones. Necesitamos una reflexión mayor -como la que promueve este Dossier- acerca de la interface entre nuestras categorías verbales y las percepciones visuales. Sin discutir a fondo estas preguntas, es posible que estemos reclamando al lenguaje visual que se adapte a las 
expectativas de nuestras categorías verbales y que funcione a contrapelo de nuestro ojo, que tiende a no hacer diferencias (salvo que las diferencias sean muy notorias).

6 3.- Si los afroargentinos pueden pasar inadvertidos es también porque la definición local de "blancura" es mucho más amplia y flexible que en los países de regímenes raciales binarios como Estados Unidos. Pero la cuestión se plantea en otros términos si, en lugar de los afroargentinos, la pregunta es por los "negros", tal como funciona la categoría nativa en Argentina cuando no se le agrega la aclaración "mota". El ojo argentino no percibe afroargentinos, pero sí percibe "negros" por todas partes, en el sentido local de la expresión: personas de fenotipos en los que se reconoce algún rasgo indeterminado pero indicativo de un linaje no exclusivamente (o no suficientemente) europeo, como piel amarronada, $\mathrm{u}$ ojos rasgados, o cabello crespo y pómulos salientes, etc. Seguramente muchos de los percibidos como "negros" son afroargentinos, pero lo cierto es que al verlos "negros" no se los considera específicamente descendientes de africanos. Aquí la tendencia es la opuesta a lo que sucede con los "afroargentinos": si a éstos tiende a no percibírselos, los "negros" están hipervisibilizados, al punto de que su negritud se transfiere al conjunto de los individuos del mundo popular, posean o no rasgos "noblancos". Las fascinantes entrevistas que analiza María Cecilia Martino permiten ver las diversas estrategias para deslizarse desde una categoría a la otra, y para utilizar las ambivalentes categorías nativas -por caso, definirse como "morocho"- para entrar y salir a gusto de la referencia a la africanidad. Esa ambivalencia, me parece, no puede ponerse solamente del lado del debe, como un mecanismo de invisibilización o negación, sino como índice de la propia inestabilidad de lo negro por relación con lo argentino.

7 Mi investigación en curso sugiere que el proceso de etnogénesis en nuestro país está inconcluso y ha sido particularmente disputado. Las élites intelectuales y el Estado han patrocinado una respuesta a la pregunta sobre cómo es el "nosotros" nacional, que lo postula blanco-europeo. De eso no hay dudas. Pero por efecto de ese carácter disputado, hubo otros modos de proponer un "nosotros", incluyendo modos que visibilizan y dan un sentido positivo, de orgullo, a esta forma de "negritud" no diaspórica (es decir, sin referencia específica a la afrodescendencia), a veces incluso en oposición a lo blanco, y siempre con un sentido de clase, popular. El peronismo y la figura del "cabecita negra" como emblema de lo popular tuvieron en ello un papel crucial. Faltan investigaciones más profundas como para poder afirmarlo con aplomo, pero es posible que sujetos con diferentes marcas de diversidad étnica -indígena, europea, "criolla", afroargentina, mestiza en cualquiera de sus variantes- confluyeran en algunas de estas reivindicaciones genéricas y clasistas de lo "negro" que, sin embargo, no recuperaban específicamente el linaje afro (ni el chiriguano, ni el mapuche, ni ningún otro en particular). Consideremos por un momento las implicancias que tendría un proceso tal, si es que existió. Supongamos probado, a título de ejercicio intelectual, que los afroargentinos definieron mayoritariamente integrarse a la nación borrando su marca étnica, tal como mostró Lea Geler para el caso de los porteños. Supongamos también probado que participaron luego en disputas por el perfil étnico-racial del "nosotros" argentino que volvían a colocar lo "negro" en un lugar central de lo argentino/popular, aunque de manera genérica, sin referencia a ningún grupo étnico particular.

8 Si todo esto fuese así, creo que el intercambio que ha permitido este Dossier puede resultar iluminador de los modos diversos en que lo "negro" puede a la vez visibilizarse y ocultarse. Se me ocurre que sería propicio continuar y ampliar el diálogo que mantuvimos aquí entre quienes se ocupan centralmente de las experiencias de los afroargentinos y 
quienes llegamos a la pregunta por la negritud desde otros puntos de partida. Pienso por ejemplo en las hipótesis con las que trabaja Diego Escolar en su fascinante Los dones étnicos de la nación, a propósito de los procesos de reetnización huarpe en la zona de Cuyo. En sentido similar al trabajo de Lea Geler, Escolar estudia la invisibilización de lo indígena como parte de un "pacto de incorporación" de los sectores subalternos, que se integran a la nación como trabajadores, sin marcas étnicas reivindicadas de manera explícita. Pero a partir de esa coincidencia aparecen caminos divergentes, que tienen que ver con la reemergencia de las marcas de etnicidad no-blanca en un contexto en el que ya no existe una comunidad huarpe de existencia empírica. Pensar la etnicidad más allá de los grupos étnicos (o más allá del "grupismo", como diría Rogers Brubaker), permite a Escolar visualizar los modos cambiantes que puede asumir el proceso de etnogénesis, incluyendo la posibilidad de que un grupo particular defina integrarse en una categoría más abarcadora que, al mismo tiempo, invisibiliza su etnicidad anterior pero re-visibiliza su diferencia étnica en un marco diferente (como podría ser, por caso, las marcas huarpe redefinidas como propias de los "cabecitas negras"). Dicho sea de paso, la idea de "fenomitos", con la que Escolar analiza los deslizamientos que se producen en la interpretación (política) de los fenotipos, alternativamente considerados "criollos", "indios" o "negros" según el contexto, resultaría particularmente interesante para repensar la interface entre nuestras categorías verbales y las percepciones visuales.

En fin, concluyo este apartado con entusiasmo, en vista de futuros intercambios que puedan ayudarnos a elaborar más y mejores maneras de entender los modos cambiantes en que puede visibilizarse/invisibilizarse lo negro en el contexto argentino, con o sin referencia a la colectividad afrodescendiente.

10 4.- Para reforzar este último punto, concluyo con la cuestión, propuesta por las editoras, de la posibilidad de usar la imagen como reparadora de las desigualdades representacionales (cuestión planteada de manera muy aguda en el texto de Caggiano). Si lo afro ha sido omitido de nuestro paisaje visual, entonces reponerlo sería políticamente deseable. La pregunta sería cómo (lo que a su vez requiere clarificar qué es lo que debería hacerse presente y de qué modo). El Estado argentino juega desde hace al menos veinte años con alternativas en este sentido, para hacer lugar a las presiones culturales que vienen de la erosión del mito de la Argentina blanca. Ya que el pueblo es visualmente irrepresentable sino mediante la metonimia (o en todo caso la alegoría), ¿qué cuerpos humanos pueden elegirse para representar al todo? Aquí existen varias alternativas. Una es, naturalmente, seguir representándolo con cuerpos de personas blancas de aspecto europeo. El video oficial del Bicentenario de 2016 -con su perturbadora predominancia de personas rubias- sería un buen ejemplo. ${ }^{1}$ Pero en años pasados el Estado intentó tematizar la diversidad por al menos otras dos vías.

11 En tiempos de De la Rúa, el video de cierre de programación que suele acompañar al himno nacional de Canal 7 intentó ponerse a tono con la política del multiculturalismo y produjo un cambio notorio. Entre los cuerpos elegidos de lo argentino incluyó, junto con las figuras típicas (el gaucho, el urbanita blanco, el militar, la Iglesia, las atracciones turísticas, etc.), toda una serie de figuras de lo que serían las "minorías" que forman parte de la nación. Allí desfilaban un par de rabinos, algún pope ortodoxo, una mujer musulmana, alguna mujer vestida como kolla, uno o dos asiáticos y un hombre con aspecto marcadamente africano sonriendo a cámara. ${ }^{2}$ Si hablamos de inclusión visual, allí el componente afro en la nación está reconocido. Sin embargo, el efecto de sentido termina siendo, me parece, el opuesto. Tal como constata Nicolás Fernández Bravo en su 
trabajo, el efecto es de exotización y extranjerización. Las minorías aparecen reconocidas visualmente e integradas, pero el video fracasa a la hora de ponerlas en pie de igualdad con los cuerpos dominantes (fracaso por el que no culparía al realizador, sino a la política del multiculturalismo que orientó sus decisiones).

Por comparación, el video que acompañaba al himno en el mismo canal en 2008 es notoriamente "homogeneizante": no hay ninguna "minoría" representada en absoluto. Son todas imágenes de un pueblo trabajador indiferenciado, encarnado en personas que son prácticamente en su totalidad de cabello negro y en buena proporción de piel amarronada (sin que pueda decirse de ninguno que sea obviamente afrodescendiente, aunque varios podrían serlo). ${ }^{3}$ ¿Cuál de las dos imagos de lo argentino es más "democrática" y tiene más potencial reparador? Desde mi punto de vista, sin duda esta última, porque consigue desestabilizar la idea de un núcleo "blanco" de la argentinidad que sin embargo permanece incólume en el video "multicultural". Pero, por supuesto, es materia de discusión.

13 Permítanme concluir agradeciendo a las organizadoras del dossier y a los demás colegas por haberme dado la oportunidad de participar en un intercambio tan estimulante que, espero, encuentre una continuidad en las páginas de Corpus.

\section{Comentario de Sergio Caggiano}

\section{Blancos que hacen de negros}

14 Los "negros tiznados", así como otras apropiaciones "blancas" de signos "negros", aparecen en varios artículos del debate. La particularidad con que aparecen en el mío me evita entrar en el tema álgido en torno a si esta apropiación permitiría una eventual afirmación de lo no-blanco (Adamovsky), o bien solo la estereotipación que reproduce la invisibilización (Ghidoli). La presencia de los "negros tiznados" en el Departamento de Documentos Fotográficos (DDF) o, más precisamente, la remoción de una de estas fotos del tema Afroamericanos y el mantenimiento de otra responde a un doble desliz. El más evidente es el que genera la inconsistencia de que una se quite mientras la otra queda. El otro desliz, anterior y más relevante, es el que hizo que previamente ambas formaran parte del tema Negros. De hecho, puede hipotetizarse justamente que aquella remoción se debe a que en algún momento se advirtió que, siendo que el tema casi no guarda imágenes de personas negras, resultaba desacertado y quizá enojoso que guardara, como mostración de los negros en Argentina, fotos de personas blancas tiznadas.

Entiendo ese primer desliz como producto de un automatismo, como parte de una rutina de trabajo, y no como producto de una decisión largamente meditada de los empleados de la institución o como aplicación de una regla explícita. Menos aun como la búsqueda de dar con la "verdadera intención" de los retratados. Pero el automatismo es político, claro está, en la medida en que es el componente básico de la reproducción de un sentido común. Los archivos encierran una historia de disposiciones políticas e instrucciones administrativas, pero también de pasos mecanizados y de descuidos. Con el tiempo, muchas decisiones estratégicas se convierten en mecanismos cotidianos, y muchas actividades reiteradas se vuelven normas consuetudinarias. La historia de estas instituciones sedimenta capas de automatismos que, en tanto tales, habilitan relaciones de poder. 

muestran perfectamente coherentes con la inhumación visual que niega, al mostrar, la presencia negra. Al lado de emblemas y objetos en desuso, de calles y edificios vacíos, y de las muy escasas y antiguas fotografías de personas negras, las de blancos tiznados refuerzan la mostración de la desaparición y de la ausencia.

Aunque implique abrir el tema a otros campos de estudio, quisiera evocar una experiencia seguramente conocida por los demás autores y autoras y por muchos lectores: la de tiznarse el rostro y el cuerpo para representar negros y negras de la Colonia en los actos patrios escolares. Detrás de este otro automatismo institucional podrían rastrearse muchas motivaciones y variaciones. Pero lo importante es que seguramente no soy el único que alguna vez se preguntó, mirando a su alrededor, si realmente era necesario que algunos de los niños y niñas se pintaran para "hacer de negro". ¿Qué hubiera implicado hacer el acto sin tizne? ¿Qué sugería esa presunta necesidad de recurrir a la pintura para contar con cuerpos "negros"?

\section{Imágenes, cuerpos y razas}

Un conjunto de preguntas propuestas por las coordinadoras del debate podrían sintetizarse en una: ¿cómo se hace visible la raza? Procurando responder algunos de los múltiples planos que esta pregunta convoca, empezaría dando un paso atrás, para decir que el análisis de las imágenes, en general, requiere de lo verbal. La historia y el análisis cultural, como la semiótica, nos enseñaron que la imagen visual es irreductible al discurso verbal, pero no puede ser independizada plenamente de este. "La dialéctica de imágenes y textos se torna un procedimiento ineludible" (Burucúa y Malosetti Costa 2012).

Por otro lado, convergentemente, el análisis de la raza requiere del discurso verbal porque la raza, como cualquier categoría, no puede constituirse fuera del lenguaje. Ahora bien, al mismo tiempo, ciertas formas de representación visual jugaron un papel clave en la configuración histórica de la raza. "En el campo de la ambigüedad y fluidez que la «raza» constituye, la fotografía y las tecnologías visuales del «tipo» que la precedieron jugaron un rol crucial en la producción del propio concepto de «raza»" (Poole 2000, p. 261 ). En resumen, existen modos de decir y modos de ver que se entretejen en la producción de la raza. El lenguaje verbal y las imágenes aportan elementos específicos y su articulación no está exenta de tensiones y contradicciones. Es por eso que, como mostré en otro lugar (Caggiano 2012), un manual escolar puede tratar la diversidad cultural y 
conjurar prolijamente el lenguaje racial, al tiempo que presentar a los "indígenas actuales" mediante la tecnología visual racializada del "tipo".

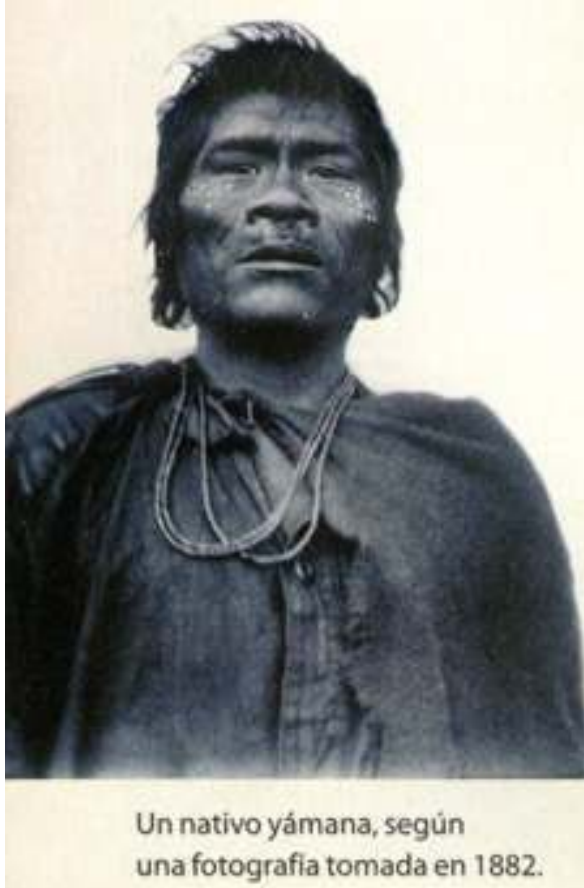

Imagen 1. "Un nativo yámana, según una fotografía tomada en 1882", Manual Tinta Fresca, Ciencias Sociales 4, 2006, p. 92.

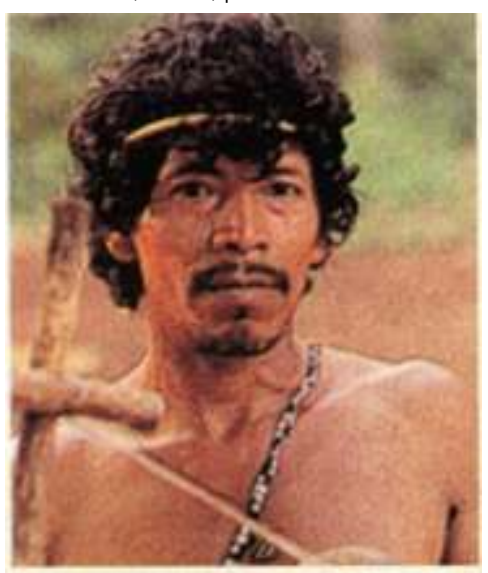

Nativo guaraniactual.

Imagen 2. "Nativo guaraní actual", Manual Tinta Fresca, Ciencias Sociales 4, 2006, p. 95.

de planos de la pregunta por cómo se hace visible la raza conduce a señalar un equívoco que sobrevuela varios de los textos de la primera ronda de este debate: que "color de piel" indica per se "raza". Como acabo de señalar, ni el color de piel ni la raza son naturalmente visibles porque nada en el mundo social e histórico puede serlo. Por lo demás, el color de piel se presenta entre las personas como un continuum, de igual manera que sucede con otros rasgos corporales. La percepción racial recorta y divide ese continuum de manera particular y lo ordena (aunque esto no significa que todo recorte sea racial).

21

¿Qué vemos cuándo vemos un color de piel?, o mejor, ¿cómo adquiere sentido eso que vemos? Mediante diversas operaciones que, si bien pueden distinguirse para el análisis, se 
activan simultáneamente. Primero, al ver apelamos a otras cosas vistas, a otros colores de piel, por ejemplo, y establecemos semejanzas y diferencias. Segundo, al ver siempre vemos un fragmento, porque lo visual es continuo y completamos mentalmente el "todo" del que forma parte; entonces vemos el color de piel en su contexto inmediato (rasgos fenotípicos, atavíos e indumentaria, etc.), y a veces proyectamos un contexto mayor. Está claro que estas dos operaciones de visión se apoyan en una historia de aprendizajes, pero el aprendizaje social se advierte todavía más claramente en la tercera operación, que hace que, cuando vemos un color de piel, veamos significados y valores asociados a él. Es que cuando aprendemos a ver y a mirar, las enseñanzas son, en gran medida, verbales, convencionales y categoriales ${ }^{4}$.

Cuando vemos un color de piel, este aprendizaje semiótico, sociohistórico y político puede hacer que lo veamos en clave racial, o puede hacer que no. La raza, en todo caso, no está en el cuerpo, sino en el modo de "verlo" (percibirlo/interpretarlo). Esto conecta con una larga discusión alrededor de las relaciones del pensamiento racial (y la raza) con el cuerpo. El color de piel es paradigmático en la clasificación racial del siglo XIX, y el racismo científico profundizará la focalización sobre el cuerpo a finales de ese siglo y primera mitad del XX. Pero hay consenso en la academia en que las articulaciones raciales anteceden y desbordan esa versión clave del racismo y las razas. Incuso hay quienes sostienen que la racialización opera sobre un plano moral más que sobre uno biológico. Inversamente, se ha señalado que no necesariamente estamos ante racialización, aun "cuando están en juego aspectos que tendemos a pensar como tales, como el color de la piel, el uso de palabras clasificatorias como «negro» o «blanco» y nociones como las de «sangre» o «herencia»" (Arias y Restrepo 2010, pp. 216-217).

Personalmente, aun sin poder atender aquí este tema por razones de espacio, creo que puede reconocerse una insistente ligazón, a lo largo del tiempo y en diferentes sociedades, entre formas de pensamiento racial y la corporalidad o los cuerpos -histórica $\mathrm{y}$ variablemente construidos- como locus explicativo, superficie de inscripción u otras alternativas. Especificar la forma que toma el racismo, la racialización y la raza conlleva interrogar las elucubraciones sobre los cuerpos.

Más allá de las discusiones acerca del "racismo cultural" y el "racismo sin razas", desarrolladas desde hace algunas décadas en Europa, no es casual que sea desde América Latina que muchos estudios llamen a analizar formas de racialización diferentes a las del racismo científico, haciendo consideraciones fundamentales sobre el lugar del cuerpo en ellas. De la Cadena, por ejemplo, subrayó la "incertidumbre fenotípica" y la "la relatividad de los rasgos somáticos en la definición de las personas" como "una de las características idiosincrásicas de las clasificaciones raciales en América Latina", que desde la Colonia otorgan a la reputación un papel cardinal, no obstante -y en convivencia con- la paulatina imposición del criterio que asoció raza a color de piel (de la Cadena 2008, p. 23). A su vez, para el caso de Brasil, Gomes da Cunha interpreta el racismo colocando en el centro a las apariencias, de las que participan el vestuario, el color de la piel y otras señales. La apariencia, no el fenotipo, promueve el encuentro en el cuerpo de "concepciones acerca de la persona basadas en modelos científicos e impresiones derivadas de las relaciones interpersonales" (Gomes da Cunha 2002, p. 534).

Exploraciones conceptuales como estas dialogan con otro de los puntos identificados por las coordinadoras para el debate: la relación problemática entre lo negro/clase social y lo negro/raza en Argentina. En otro lugar, Adamovsky mostró persuasivamente las distinciones, como también -tarea más ardua- las conexiones históricas entre ambas 
(Adamovsky, 2013; ver también Frigerio 2006, 2009; Geler 2013, 2016). Continúa mostrándose fecundo el interrogante por la corporalidad en estas conexiones y desconexiones. Ideas como la de la "incertidumbre fenotípica" o el "racismo por apariencia" ofrecen pistas para atender el lugar del cuerpo en las figuraciones raciales y clasistas y en su imbricación ${ }^{5}$.

\section{Argentina: la invisualización de los negros} particularidad que parece funcionar como hipótesis común de todos los textos de la primera ronda del debate: que "invisibilización" de afrodescendientes puede entenderse aquí lisa y llanamente como "invisualización". No se trata únicamente de que se escatime la participación negra en la historia, de que se subvalore su presencia en el pasado y en la actualidad, que se deniegue el reconocimiento. Se trata de una maniobra que alimenta las anteriores pero es más elemental, y consiste en una pedagogía de la mirada que enseña a no ver lo negro en la historia moderna argentina y a no verlo en los cuerpos, al tiempo que enseña a verlo en el pasado lejano y en el extranjero. Por ello los diferentes artículos de la primera ronda, atendiendo distintos temas y problemas, más tarde o más temprano tienen que vérselas con la tarea primordial de producir, reinterpretar o buscar y restituir imágenes.

El papel político de la producción o restitución de estas imágenes de afroargentinos o negros abre diversas alternativas: la clase / negritud popular, la raza / diáspora, la etnia / comunidad y otras. Estas alternativas diferentes comparten, sin embargo, un momento anterior, el punto de partida en que nuestros distintos trabajos se tocan y comunican, que viene dado por la dislocación del sentido común que postula una Argentina blanca. Ese momento anterior a las formas de clase, raciales, étnicas que puede tomar la politización de las imágenes de negros requiere "simplemente" mostrar la Argentina no blanca, así como los vacíos que habitan constitutivamente su pretensión de blancura. Si hay en la imagen algún potencial reparador de las desigualdades representacionales, este tiene que ver con mostrar lo no blanco en la historia y en la actualidad argentinas.

Tiene que ver con esto que yo proponga hablar de "existencia negada", como la forma particular que toma la invisibilización a la que refieren también otros colegas (vgr. Ghidoli). Fernández Bravo recupera la idea de Hirsch y Gordillo de una "presencia ausente" de los grupos indígenas en el imaginario nacional, para proponer la de "ausencia ausente" de los afroargentinos, buscando con ello subrayar la radicalidad de la invisibilización. Por mi parte, creo que la noción de "existencia negada" da mejor cuenta de la referida particularidad de esta invisibilización. Como creo haber mostrado en el caso del DDF del Archivo General de la Nación, los temas Negros, primero, y Afroamericanos, después, dan entidad oficial a la categoría, al tiempo que las imágenes concretas que el tema reúne niegan la existencia de lo que la categoría nombra. El mecanismo puede rastrearse en otros artefactos culturales, y es análogo al de la reiterada frase "en Argentina ya no hay negros", no tanto si pensamos en el enunciado, como si consideramos el nivel de la enunciación. En la frase, como en los reenvíos entre el Índice Temático y las cajas del archivo, se pone en acto la negación. Entonces la existencia aparece negada. El acto no desaparece a los negros y las negras: los niega.

Quisiera concluir con una anécdota que no proviene de mis investigaciones, sino de mi vida personal, pero que sirve para transmitir mi inquietud intelectual y política acerca de 
esta negación de la presencia. Hace unos pocos años, en una visita al pequeño pueblo de la provincia de Buenos Aires donde me crié, tomé un taxi tras llegar a la terminal de ómnibus y, como acababa de regresar al país tras un buen tiempo en Brasil, ese dato rápidamente formó parte de la conversación. El taxista vio la posibilidad de compartir, entusiasta, una vivencia. Me contó que unos años antes había viajado a Brasil en automóvil. "Fue increíble -dijo-, no bien cruzamos la frontera, empezaron a confundirme, a decirme que era brasilero; me dijeron muchas veces que si yo era brasilero. Y yo les decía, «no no, yo soy negro, pero no soy brasilero, soy negro pero soy argentino»". Su relato evoca un imaginario nacional racializado que comparte, que distribuye colores de piel a un lado y otro de la frontera, al tiempo que llama la atención sobre la mirada reflexiva y crítica del protagonista acerca de dicho imaginario.

\section{Comentario de Nicolás Fernández Bravo}

Los cinco trabajos presentados para el dossier presentan un amplio rango de situaciones epocales y geográficas, dando cuenta de una primera paradoja: mientras que los esfuerzos por poner en evidencia la existencia de imágenes e imaginarios sobre "lo negro" advierten una visibilidad difusa, su relativa magnitud señala un conjunto significativo de imágenes que pone en entrevero las razones y la eficacia misma de la invisibilidad, volviendo especialmente relevante la idea de una ausencia ausente.

31 En este diálogo con los distintos autores, propongo centrar el debate en torno a la dimensión política de la representación visual de "lo negro": quién representa qué y para qué. Aquí se presenta una primera dificultad, que a su vez puede operar como conjetura ordenadora de la temática en cuestión. Habiendo distintas formas de nombrar una problemática escurridiza como lo es la representación visual de una ausencia colectiva, la idea común que impera detrás de todas las imágenes analizadas, es la existencia de fotografías con personas negras. Si las miradas de los investigadores están cruzadas por este factor, lo mismo puede suceder con quienes observan esas imágenes, sin importar el contexto que condicione la política del nombramiento (esclavos, negros, mulatos, afrodescendientes). De una u otra manera, con independencia del tiempo y el espacio, la presencia del marcador racializado constituye un elemento que le otorga un recorte específico al modo de mirar esas fotografías. Ahora bien, la estrategia representacional, acertadamente señalada por Adamovsky para el caso de las imágenes del criollismo, puede extenderse a la totalidad de las imágenes escogidas por los autores a partir de variables que trascienden el mero marcador racializado.

Todos los trabajos señalan una condición oscilante, cambiante y ambigua en las políticas de representación visual de "lo negro". Desde un punto de vista metodológico, si bien cada autor realiza un recorte arbitrario para dar cuenta de una dimensión específica de su análisis, dicho recorte resulta ser exhaustivo y respetuoso de los interrogantes en torno a las relaciones de poder entre los representados y la representación hegemónica que se estaba produciendo sobre ellos. Tanto las mutaciones de lo negro/grotesco analizadas por Ghidoli, como la ambigüedad de lo mestizo/criollo presentadas por Adamovsky, son históricamente contextualizadas por ambos, mientras que Caggiano, al centrarse en los criterios de clasificación del Archivo General de la Nación, pone en evidencia la presión en parte producida por los propios representados - por cambiar los criterios de denominación del conjunto. Para el caso de Martino y mi propio estudio, las imágenes de los representados coexisten temporalmente con ellos mismos y sus propias 
interpretaciones. Se pudo participar etnográficamente de las tensiones y disputas sobre las fotografías, al punto extremo de presentarse situaciones que culminaron por obturar su circulación pública.

A lo largo del tiempo, las ambigüedades señaladas por los autores fueron (y continúan siendo) objeto de disputa política. Observadas desde el presente, tanto las imágenes grotescas como las gauchescas, como así también las de pujanza y orgullo-alegre, permitieron construir antagonismos políticos con significados sorprendentemente vigentes. Resulta interesante señalar cómo algunos de estos elementos en tensión, fueron reapropiados por el peronismo en clave positiva, tanto para el ejemplo propuesto por Adamovsky en el caso de Juan Pueblo y su asociación con el "futuro pujante de la patria", como por los usos de imágenes publicitarias propuestas por el peronismo kirchnerista, durante la campaña realizada con anterioridad al Censo Nacional de Población del año 2010. Este último contexto político acaso necesite una mayor profundidad de análisis, toda vez que en él se pusieron en juego dimensiones de un potencial inexplorado - y la producción de imágenes jugó un rol determinante. Para el caso de dos imágenes identificadas -pero no estudiadas en esta selección- en las que posaron argentinos de origen caboverdiano, su simple aparición en el contexto de una campaña censal nacional es un ejemplo sintomático de la voluntad y presión por ser identificados visualmente como afroargentinos, toda vez que en muchos casos se trata de personas de tercera y cuarta generación. En estos casos, el uso que algunos activistas pueden realizar de estos acontecimientos, permite pensarlo como una efectiva politización de la imagen, o un uso político de la identidad visual. Acaso ilustre como ningún otro caso, un sentido colectivo de la autorrepresentación.

Del mismo modo que la perspectiva de una estrategia representacional permite interpelar el trabajo de todos los autores, la idea de distintas esferas de circulación puede ser especialmente fértil para pensar la política de la representación de los distintos casos. Aquí, lo doméstico, lo político y lo público se relacionan de distintas maneras, e incluso cambian a lo largo del tiempo. La dimensión doméstica es evidente en el caso de Martino, quien trabaja sobre fotografía y familia, pero opta por no incluir masivamente imágenes fotográficas en su estudio, señalando un límite en cierto modo político. Del mismo modo, es revelador el ejemplo escogido por Adamovsky para ilustrar el uso de las imágenes de un casamiento criollista en cuya ceremonia no podían faltar los negros. Incluso algunas fotografías de archivo estudiadas por Caggiano, probablemente hayan tenido un origen familiar antes de devenir en -unas pocas- fotografías públicas. Aquí es necesario a su vez distinguir en dos usos diferenciales de lo público: mientras que las imágenes del Archivo General de la Nación ocupan un lugar y un estatus oficial, las imágenes de almanaques o de la prensa gráfica estudiadas por Adamovsky y Ghidoli, no siempre se encuentran adecuadamente conservadas en contextos públicos. En algunos casos, pueden ser identificadas en archivos oficiales, pero en muchos otros, circulan (o se estancan) en la esfera del mercado y la vida privada, donde posiblemente existan muchas otras imágenes "invisibilizadas", al igual que en potenciales álbumes familiares cuya ubicación y valor desconocemos.

Sin embargo, con la excepción mencionada para el caso del Censo Nacional de Población, las formas de la autorrepresentación de imágenes de negros en Argentina, es aún incipiente. Los trabajos presentados permiten concluir que la gran mayoría de las representaciones aún se encuentran signadas por una relación colonial, en la cual el dominio de la imagen (quién y para qué) se encuentra sobre determinada por otros. 
Pensando en términos de circulación, es posible afirmar que éste sea uno de los factores por los cuales muchas imágenes familiares -conservadas en archivos domésticos, olvidadas de toda memoria- no encuentren motivos para ocupar un lugar en la esfera pública. Es en la esfera íntima y doméstica en donde esas imágenes, ausentes de toda ausencia, aún encuentran un territorio autónomo.

\section{Comentario de María de Lourdes Ghidoli}

La propuesta de Eva Lamborghini y Lea Geler en torno las imágenes racializadas con énfasis en "lo negro" en Argentina han dado como fruto un corpus visual sumamente heterogéneo desde diversos aspectos. En primer lugar, el más evidente y esperable debido a las líneas de investigación de los participantes, ha sido el abordaje de distintos períodos y de distintos tipos de soporte de la imagen por parte de quienes en él participamos. En consonancia con esto, existen diferencias que surgen de los modos en que cada investigador indaga en ellas desde su campo disciplinar.

Como primer paso se vuelve necesario caracterizar lo que se entiende por imágenes racializadas o por lo menos intentarlo. Desconocer información vinculada a las imágenes que se examinan deja al investigador como posibilidad inmediata la asignación de una identidad afrodescendiente a partir de rasgos fenotípicos, dejando asentado que esta práctica constituye un peligro latente. En ocasiones sólo queda emprender la pesquisa a partir de esta lectura fenotípica aunque necesariamente ligada a un conocimiento del tema que permite suponer esa categorización racial, la negritud en nuestro caso. Respecto de este término, Geler (2016) diferencia dos nociones operativas (toda vez que se trata conceptos fluctuantes) la negritud racial, aquella asociada con unos pocos rasgos que se presentan de manera conjunta y que anclan tanto en lo visual como en lo biológico: pelo mota, piel oscura, labios gruesos, nariz ancha; y la negritud popular, vinculada con categorizaciones sociales y 'formas de ser' que no sólo incluye a los afrodescendientes. En este punto cabe consignar que hacia fines del siglo XIX este grupo de población "sirvió de marco para la negritud del mundo popular, de la plebe o de las que devendrían 'clases obreras"' (Geler 2010, p. 19). Quisiera además señalar que el marco temporal en el que se producen las imágenes juega un rol relevante en la presunción de afrodescendencia de los representados. Considero que para imágenes provenientes del siglo XIX (especialmente pinturas o grabados ejecutados con anterioridad al auge de la fotografía) esta asignación resulta menos problemática pues no solo intervienen en ella los rasgos fenotípicos sino también los contextos históricos (guerras del siglo XIX, rosismo, liberalismo), las vestimentas y adornos, los roles sociales o laborales desempeñados por los representados, en una etapa en la que la negritud popular era aún embrionaria.

En el estudio de representaciones racializadas, a la no transparencia de las categorizaciones raciales se agrega la opacidad de las imágenes, su inherente polisemia, una polisemia incluso de mayor grado que la que corresponde al lenguaje, y que puede dar lugar a ambigüedades. Es por ello necesario que la imagen y la palabra se traspasen mutuamente y que la eficacia de la primera sólo pueda ser percibida por medio de la palabra que busca otorgarle un sentido unívoco (Marin 2009 [1981]). En un corto pero esclarecedor artículo acerca del uso de imágenes como fuentes históricas para acercarnos a lo real que existe más allá de las representaciones, Burucúa y Malosetti (2012) demuestran que los intentos por crear un corpus de imágenes sin vínculos con discursos escritos terminan inevitablemente en fracasos. Dos ejemplos nos traen los autores: la 
inclusión de dos capítulos compuestos sólo de imágenes en Modos de ver de John Berger (2005 [1974]) y el Atlas Mnemosyne (1924-1929) concebido por Aby Warburg como memoria en imágenes de asuntos que consideraba fundamentales para la historia de la humanidad. La falta de textos en ambos casos implica derivas de sentido que confunden la comprensión de lo que se muestra. Pero no todo queda circunscripto al significado que se le otorgue a una imagen. En nuestro caso existe un discurso racializado que no necesita de otra cosa para ser proferido. Sin embargo su entrecruzamiento con imágenes visuales lo transforma ( $\mathrm{y}$ a su vez este cruce transforma la imagen) pudiendo fomentar $\mathrm{u}$ obstaculizar aquel discurso.

Los trabajos de Martino y Fernández Bravo nos colocan frente a la pregunta de cuán delgada es la línea que separa la representación de la autorrepresentación visual de individuos. En una primera y simplificada aproximación podría decirse que una autorrepresentación es tal cuando es realizada por el protagonista de la imagen. Sin embargo esta afirmación dejaría por fuera, entre otras, toda imagen que incluyera más de una persona. Cabe aclarar que para el caso de imágenes de afroargentinos o afrodescendientes, a pesar de que algunas imágenes nos muestren a personas únicas, no nos referimos a individuos aislados sino a un colectivo. Esta definición de autorrepresentación debe ser matizada pues una imagen no sólo tiene entidad a partir de su creación, vale decir de alguien que efectivamente la ejecutó, sino que se enmarca dentro de una cultura visual en la cual son fundamentales tanto la producción, como la circulación y la recepción de esas imágenes. Y sobre todo, en el tema que nos ocupa, el uso que los representados hacen de ellas. En este sentido el texto de Martino en el que da cuenta de la entrevista realizada a Analía se pone en evidencia que las fotografías son manipuladas casi como una autorrepresentación de un colectivo, los caboverdeanos. Aunque no se aclara quien realizó las fotografías del casamiento, si un familiar o un fotógrafo contratado, en este caso parece no importar cuando se busca tomarlas como prueba de una identidad. El señalamiento de un conjunto de rasgos fenotípicos como indicadores de una ascendencia caboverdeana ubica a aquel grupo de fotografías en la categoría de autorrepresentación toda vez que Analía las utiliza para validar su identidad y la de su grupo de pertenencia. Hablamos de fotografías concebidas para circular en un ámbito privado, particular, pero que son utilizadas con posterioridad por la entrevistada para dar cuenta de una generalidad, pues considera que permiten reconocer a los miembros de su colectivo. Es interesante además que la propia entrevistada no aparece (lo presupongo pues se trata del casamiento de sus padres) en esas imágenes lo cual invalidaría la noción de autorrepresentación.

En el análisis de Fernández Bravo las fotografías juegan de manera muy distinta. En esta ocasión se conoce la autora de las imágenes, una fotógrafa blanca de clase media según consigna el autor, y esta condición racial y social sobrevuela la imposibilidad de considerar estas imágenes como autorrepresentaciones. No obstante, y entendiendo las imágenes dentro de una cultura visual, considero que aún no han cruzado esa delgada y permeable frontera que divide las representaciones de las autorrepresentaciones. Especialmente porque los propios retratados, como colectivo, no se han apropiado de ellas. Es probable que exista una apropiación individual de alguna de las fotografías pero esa práctica no implica una búsqueda identitaria como ocurre en el caso analizado por Martino. Por supuesto esto es pasible de modificarse en un horizonte político-cultural considerado adecuado por los representados. En tal caso su apropiación, entendida como aquella que implica una construcción de sentido a través de los usos e interpretaciones de 
los objetos culturales (Chartier 1990), puede volverse necesaria y convertir el uso de esas imágenes en una herramienta poderosa para negociar la pertenencia del colectivo a la nación. Vale decir, apropiarse de ellas en función de la promesa que pueden encarnar de cara a las desigualdades no solo representacionales sino principalmente cotidianas (dificultad en el acceso a recursos de todo tipo), como señalan Fernández Bravo y las coordinadoras de este debate.

Quisiera en este punto reflexionar acerca de las imágenes aisladas, huérfanas de contexto como algunas de las preservadas en el DDF analizado por Caggiano. Como señalé previamente, las imágenes producen efectos a partir de enunciados que buscan fijarlas a un sentido. Sin embargo, las imágenes tienen a su vez la capacidad de emocionarnos, enojarnos, enternecernos, vale decir producir en nosotros algún tipo de estado emocional aun fuera de todo contexto. Ahondar en él podría profundizar estas emociones, dejarnos indiferentes o generar emociones contrarias. Pero si lo que se busca es usar las imágenes como prueba, como medio de argumentar acerca de algún tópico, el conocimiento del contexto se torna indispensable. Asimismo, respecto de las fotografías Tell (2011, p. 232) indica que "no suelen estar solas, rara vez hay una única foto en algún lado. El reagrupamiento en álbumes o archivos es en cierta medida natural para estas imágenes que hallan en las vecinas acompañamiento, anclaje, ampliación de sentidos". Esto se aparta de lo que sucede en el repositorio que analiza el autor, que se vale de rótulos bajo las cuales, en no pocas ocasiones, el conjunto de imágenes que contiene se encuentran descontextualizadas, como ocurre con aquellas contenidas bajo la etiqueta afroamericanos (¿por qué no afroargentinos?). Haré foco en una de ellas en la que, como indica Caggiano, la ausencia de personas choca con las expectativas que genera el rótulo que las contiene y mostraría no sólo la desaparición de los afroargentinos sino, según su nominación, también la desaparición de los afroamericanos. En este sentido el paso de negros a afroamericanos es también un síntoma de la negación de la presencia afroargentina. Ya he señalado la necesidad del cruce entre palabras e imágenes para conferir a estas últimas un sentido específico. En este caso la leyenda escrita al dorso de la foto no aporta demasiado, sólo un título descriptivo (mesa presidencial de la Sociedad de Negros «Nación Benguela) y una fecha incierta (fines siglo XIX). Nada que permita vincular esas imágenes con los afroargentinos si no supiéramos de la existencia de sociedades africanas en la Buenos Aires del siglo XIX. Y poco que permita vincularla con las otras imágenes con las que convive en ese espacio y con las que tiene lazos importantes como veremos más adelante. Didi Huberman (2012 [2007]) ha indicado que los archivos se pueden caracterizar como "ese laberinto compuesto tanto de intervalos y huecos como de material observable", es decir que prevalece en ellos una lógica fragmentaria según la cual esos fragmentos no son reflejo ni prueba de lo que muestran. Por ello, señala el autor, "el archivo debe ser trabajado mediante cortes y montajes con otros archivos" (Didi Huberman 2012 [2007]) produciendo así conocimiento a través de ese montaje. Pero, cómo establecer esos cortes y yuxtaposiciones cuando el archivo es casi mudo, cuando deliberadamente, como en el caso de la imagen del DDF, no da pistas a seguir. Un golpe de suerte o el arduo relevamiento de diversas fuentes ilustradas (periódicos, revistas entre otras) nos permitiría llegar a algún puerto. En la revista Caras y Caretas del 15 de febrero de 1902 aparece reproducida la imagen en cuestión junto a otras tres en una nota titulada "El carnaval antiguo. Los candomberos". Dos de ellas son las que refiere Caggiano como una serie de instrumentos musicales "de negros candomberos y "dos morenas representantes del carnaval antiguo". Lo que ha ocurrido aquí es lo inverso de lo planteado por Tell. Las imágenes fueron extraídas del archivo visual al que 
pertenecían (Caras y Caretas) para conformar un nuevo archivo, en este caso mudo pues las imágenes no establecen relaciones mutuas que estructuren un relato ni establecen relación con quien las observa o con algún texto, obturándose así la posibilidad de significar. Debemos decir, sin embargo, que este repositorio fue creado hace varias décadas, y seguramente conservado sin demasiadas modificaciones desde su instauración. De ello da testimonio el reciente cambio del rótulo "negros" a "afroamericanos" que no partió de la propia institución sino que se instrumentó ante el pedido de una investigadora. A pesar de este cambio, como demuestra Caggiano, su contenido casi no ha mutado y mantiene un escueto espacio. La interesante cantidad de preguntas que se/nos hace el autor son de respuesta muy compleja y hasta subjetiva. Queda seguir indagando en el archivo, emprender el fructífero e imprescindible cruce de palabras e imágenes en pos de ubicar en la trama histórica esos fragmentos, a veces inasibles, preservados en el archivo.

Por su parte, el trabajo de Adamovsky nos permite acceder a imágenes de afroargentinos producidas en la primera mitad del siglo XX, un período en el que tales imágenes escasean o son poco visibles en comparación con las provenientes del siglo XIX. Las mismas se enmarcan dentro del discurso criollista y el autor demuestra que se erigieron en vehículos eficaces para tematizar la heterogeneidad étnica de la nación en un momento en el que se dificultaba hacerlo a través de planteos verbales. A partir de ello inferimos que el cruce entre textos e imágenes dio por resultado no sólo esperables convergencias sino también discrepancias importantes entre ambos discursos. Sin embargo, propongo que específicamente en lo que refiere a la visibilización de los afroargentinos se podría pensar en una visibilización engañosa. Tanto su presencia efectiva, como la mujer ataviada con un vestuario asignado al colectivo femenino afrodescendiente anclado en la época colonial de la Fiesta criolla, como su presencia virtual, a partir de las formas grotescas y estereotipadas que implica embetunarse el rostro, nublan la posibilidad de hacerlos visibles. Considero que no sólo basta con la inclusión de personajes negros en las imágenes o en las artes del espectáculo sino que resulta fundamental analizar de qué manera se los incluye, qué rol juegan en esas puestas en escena, qué nos dice ese modo de incorporarlos al imaginario nacional del criollismo, y pensar si las diferencias y similitudes que se presentan al confrontarlas con otras imágenes de los afroargentinos dan cuenta efectivamente de una visibilización.

Para finalizar me referiré a una fotografía de la nación Camundá (Figura 2 del texto de Fernández Bravo) buscando inscribirla en sus contextos de producción original y reproducción contemporánea con el fin de indagar en una de las preguntas planteadas por Fernández Bravo: por qué, a pesar de su creciente circulación, esta imagen no logra hacer visible la presencia afroargentina en nuestra sociedad. En ocasiones parece no importar de dónde proviene una fotografía, quién la tomo, en qué universo de fotografías está/estuvo inscripta. Esto ha ocurrido con nuestra imagen que fue incluida inicialmente en un artículo de Caras y Caretas de 1908 (Imagen 3 y 4) pero pocos parecen reparar en ello. Quiero decir pocos reparan en lo que dice aquel artículo. ${ }^{7}$ A lo largo del texto el cronista se lamenta y culpa a los camundá por haber desaparecido y abandonar su patrimonio: “¡Cuánto mejor negocio no hubieran hecho los camundás negándose a desaparecer, a ser proyectados a parte alguna por no importa qué fatalidad, permanecido dentro de los límites de su candombera nación ${ }^{8}$ (...)”. A su vez es interesante señalar que esa nota incluye nueve fotografías en sólo dos páginas, de las cuales la que ha circulado y circula en la actualidad, es la de los niños con los tambores. Pero ¿por qué presupone el 
cronista que ninguna de las personas que aparecen en las fotografías (y aquí aplicamos un reconocimiento fenotípico) visiblemente negras sea descendiente de los Camundá? Este artículo es uno más de los tantos que se publicaron en Caras y Caretas en los primeros años del siglo XX y en los que se enfatizaba en la irremediable extinción de este grupo de población a pesar de que las imágenes que 'ilustran' esos textos lo contradicen. De su lectura vemos que la idea de ausencia ausente propuesta por Fernández Bravo está funcionando casi desde los inicios mismos de la consolidación del proyecto de nación de fines del siglo XIX. ¿Es posible que estemos en presencia de un proceso que hunde sus raíces en la trata negrera cuando los esclavizados no eran consideradas personas sino objetos negociables? En una investigación previa (Ghidoli 2016) he propuesto, a través del cruce de documentos icónicos y escritos del siglo XIX, que el proceso de invisibilización sufrido por la población afrodescendiente en Argentina -un proceso que conduce a la falta de individuación, la marginalización y la desocialización del grupo en cuestión- tuvo lugar a lo largo de todo el XIX y no solo en sus décadas finales. Es posible que las estrategias discursivas y visuales que proliferaron hacia fin de siglo vinieran a apuntalar concepciones activas en la sociedad que necesitaban reforzarse ante la capacidad de agencia que demostraban los descendientes de africanos esclavizados. Esta pregunta también podría ser planteada en el presente si tenemos en cuenta que gran parte de la 
población nacional asume la no existencia de negros en el país y circunscribe su presencia como esclavos en la época colonial.

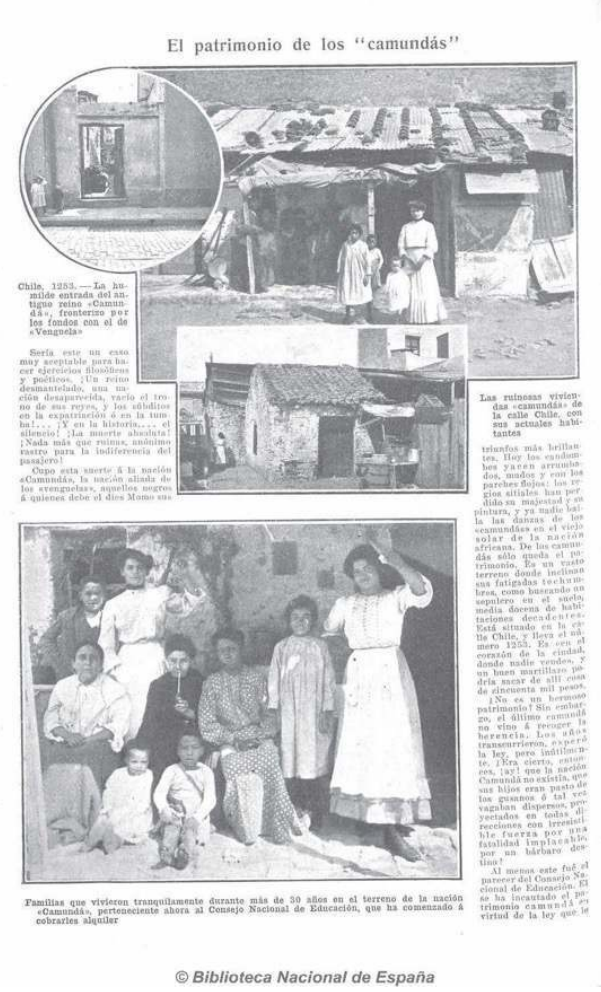

Imagen 3. Revista Caras y Caretas.

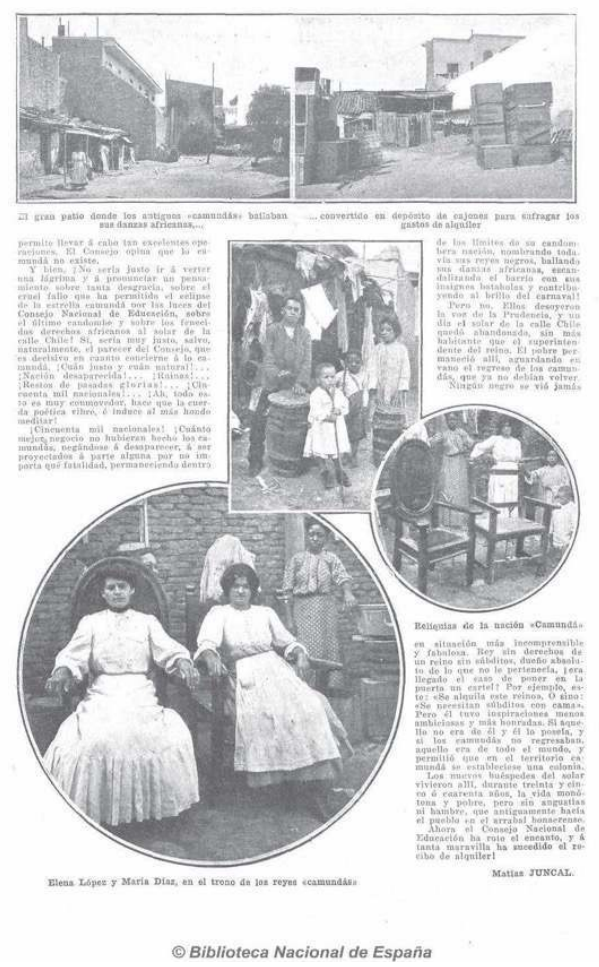

Imagen 4. Revista Caras y Caretas.

Volviendo a la imagen, en la contemporaneidad circula con cierta profusión, especialmente en las redes sociales y sitios de internet. Considero que la mayor visibilidad 
de esta imagen se corresponde con esos medios digitales pero su puesta a disposición de la mirada ampliada se debe a su aparición en la revista Viva en mayo de 2011. Asimismo esta última inclusión merece ser vista en relación con el texto que acompaña. La nota fue publicada con motivo de la muestra fotográfica La villa. Dignidad y miseria (Pabellón de Artes de la UCA) inaugurada por esos días y compuesta de imágenes fechadas desde inicios del siglo XX hasta la contemporaneidad (entre las que sugestivamente sólo hay una correspondiente a los años de los dos primeros gobiernos de Perón). Se trata de aproximadamente 160 fotografías referida a villas y asentamientos en los que viven grupos poblacionales de escasos recursos. El título bajo el cual se exhibió la imagen que examinamos es Afroargentinos en la Villa. Comunidad Camundá (Equipo de fotógrafos de Caras y Caretas, Buenos aires 1908). El título, arbitrario, se ajusta al contexto actual (como ocurre con el rótulo del DDF) pero a su vez pone en evidencia su descontextualización si nos remitimos a la nota original en la cual vio la luz. Si la idea de la muestra era dar cuenta de las condiciones precarias de supervivencia de grupos sociales marginados y se creyó necesario incluir la presencia afrodescendiente (evidentemente asociada al pasado), por qué seleccionar la foto de los niños con tambores teniendo a disposición otras imágenes del mencionado artículo de 1908 que serían más oportunas. Pero seguramente menos pintorescas. Esta decisión podría vincularse con las búsquedas estetizantes de algunas exhibiciones a pesar del carácter documental que la temática impone.

Es indudable que las imágenes adquieren una vida social propia que deriva en interpretaciones cambiantes según el ámbito en el cual se inscriben. Como vimos nuestra fotografía no escapa a ello. Recientemente un afroargentino (Juan) me mostró esta imagen preguntándome si la conocía. Era motivo de orgullo para él y una manera de refrendar la presencia afro en la nación. He insistido a lo largo de este escrito sobre la descontextualización, consciente o no, de las imágenes que da lugar a la imposibilidad de enunciar un significado estable. En ocasiones los investigadores denunciamos el uso de imágenes que anclan a los afrodescendientes al pasado reclamando su puesta en relación con imágenes contemporáneas que permitan dar continuidad a la presencia de los afrodescendientes en el país. Pero, qué ocurre cuando los propios afrodescendientes hacen uso de esas imágenes del pasado. Evidentemente para Juan, quien puso ante mis ojos la fotografía, no era necesario dar cuenta de imágenes contemporáneas pues su propia presencia frente a mi estaba marcando su pertenencia a la nación. La ceguera es nuestra, a pesar de tenerlos delante no los vemos. Una condición (la ceguera) que, según nos muestra la historia y las prácticas cotidianas, resulta difícil de revertir pero imprescindible de abordar. A pesar de que no sepamos aún cómo hacerlo.

\section{Comentarios de María Cecilia Martino}

\section{Apuntes y reflexiones sobre los modos de la auto-representación}

En esta instancia buscaré ampliar y analizar algunos ejes propuestos por las coordinadoras de la publicación para desplazarme desde éstos hacia otros presentados por los autores que participan del presente debate. Partiré de la dimensión referida a las representaciones y las autorrepresentaciones retomando en algunos casos las "escenas" a las que aludí en el trabajo presentado y en otros, ampliando la información sobre otras situaciones. 
47 El primer conjunto de imágenes al que hice referencia tiene la particularidad de estar compuesto por fotografías familiares, tomadas y organizadas por miembros de un grupo familiar específico, para luego fijar su sentido una vez dispuestas en las paredes o estantes.

Su estatus de autorrepresentaciones no debería sin embargo darse por sentado. El paso del tiempo y la renovación generacional las tornan discordantes, o las personas pueden no sentirse particularmente representadas por ellas.

49 Estas fotografías no hablan por sí mismas. Es de la historia de la que provienen estas fotos, de los relatos que las describen, de sus apropiaciones y de las relaciones que expresan que podría determinarse una dimensión racial en éstas. Por este motivo consideré central articular imágenes a situaciones o "escenas" para contextualizar su sentido, dado el carácter inherentemente polisémico en toda fotografía para, en términos de Ghidoli, reconstruir aquellas tramas racializadas de lo visual. Como indica Fernández Bravo, este carácter ambiguo, sin embargo, no le quita a la fotografía su fuerza evidencial ya que estas imágenes se anclan en una porción de lo real, cuyo sentido sin embargo no se agota en la fotografía. Por este motivo su contextualización histórica y etnográfica se hace necesaria.

50 Las situaciones que analicé muestran a los retratos en movimiento, mediados por relaciones y narrativas que los cuestionan o los justifican. Incluso el efecto de permanencia transmitido en las fotografías se reafirma en su fuerza para proyectar la continuidad de relaciones y modelos familiares que gozan de una mayor legitimidad social. Entonces, si bien las referencias explícitamente racializadas emergen, son redefinidas, retocadas y reinterpretadas para relativizar sus sentidos.

51 En cuanto al segundo conjunto de fotografías analizadas en el texto anterior, -las imágenes fotográficas presentes en documentos-, señalé que éstas fueron utilizadas en algunos casos para fortalecer autorrepresentaciones. En algunas de las situaciones conversacionales en que se hacían presentes los documentos personales, su importancia como momento de constatación del origen europeo-portugués ${ }^{9}$, resultó efectivo al reforzarse con el simbolismo oficial. En efecto, la narrativa migratoria de finales de siglo XIX y principios del XX fue tradicionalmente conocida por remarcar el origen blancoeuropeo en todos los ámbitos donde se hizo presente.

52 Analicé las situaciones de discordancia, cuando la declaración del origen europeo interactuaba con las marcaciones racializadas presentes en estos documentos permitiendo a las personas rectificarlas. Sin embargo, la corrección no era del todo eficaz, y por ello abría un espacio de tensión e indeterminación que, como sugiere Adamovsky para el caso del criollismo local, ${ }^{10}$ permitió establecer conexiones con diversas manifestaciones de una identidad no blanca.

53 Efectivamente, esta corrección establecida por los entrevistados a las imágenes no hacía desaparecer la marcación, permitía más bien eludirla. En Buenos Aires las clasificaciones raciales del colonialismo se venían redefiniendo a partir del traslado censal hacia la categoría de "trigueño" que ofrecía, dada su indeterminación, la posibilidad de "escapar" de las categorías coloniales previas (Andrews 1989). Esta nueva denominación, produjo una desaparición censal que apuntaló la narrativa temprana sobre la ausencia de afroargentinos. En algunos documentos expedidos en Argentina a familias argentinocaboverdeanas figura esta denominación (trigueño) mostrando la materialidad de este proceso de progresiva desmarcación censal apropiada por las personas en diferentes 
ámbitos de su vida cotidiana. Las fotografías ${ }^{11}$ que a continuación se muestran dan cuenta de la vigencia de esta denominación en el tiempo.

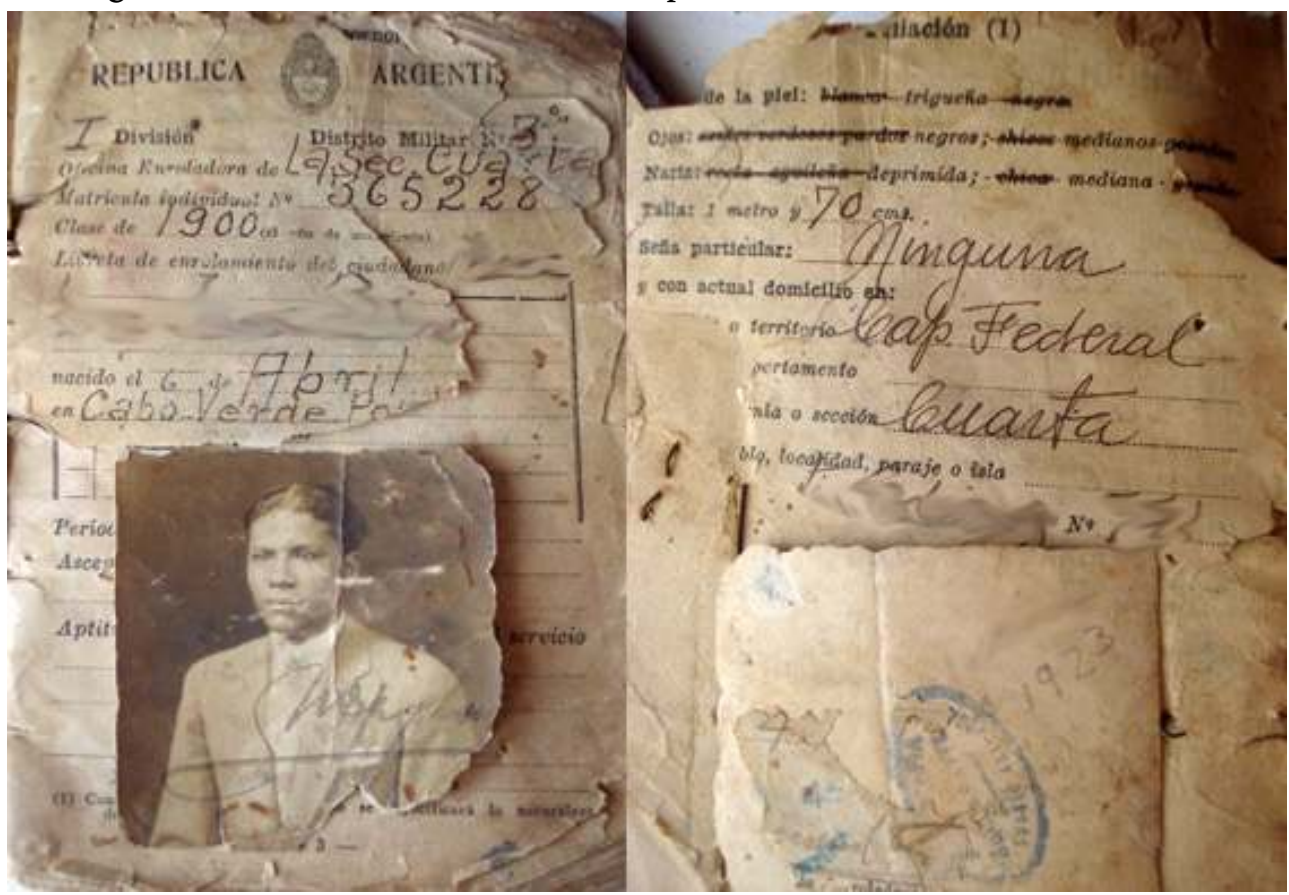

Imagen 5: Libreta de Enrolamiento. Año 1930 (aprox.). Se observa la denominación "trigueño", junto a otras descripciones físicas.

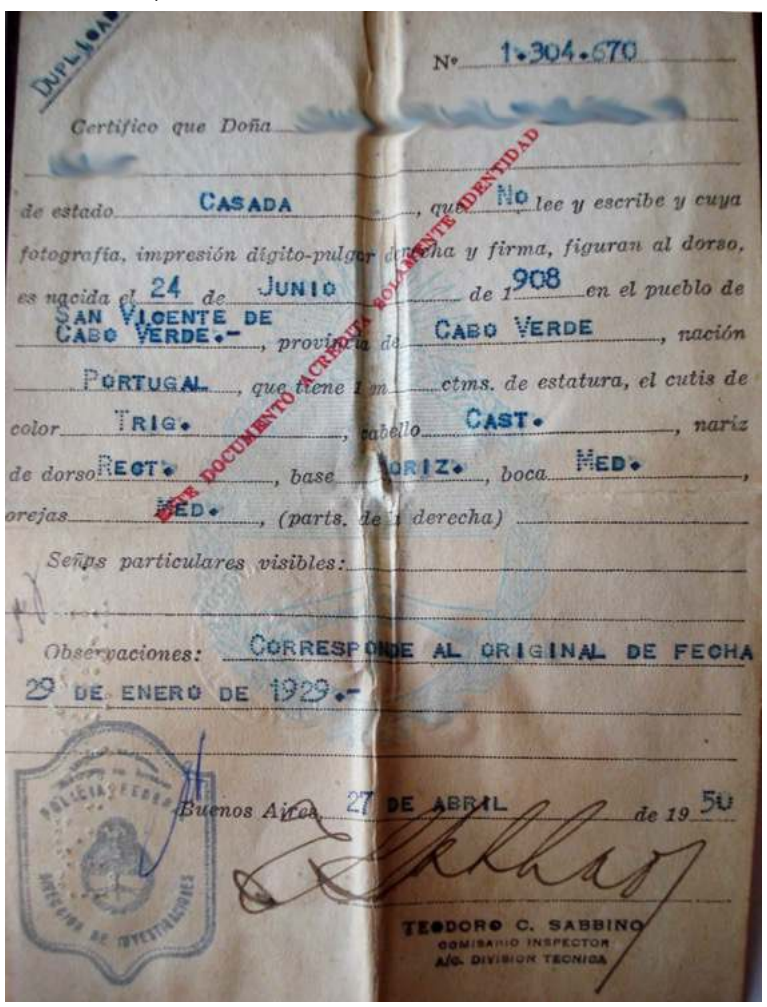

Imagen 6: Libreta Cívica. Año: 1950. Se observa "trig" junto a otras descripciones físicas.

En otras palabras, el lugar y significado de la fotografía es redefinido y rectificado de distintas maneras a lo largo del tiempo para fortalecer diferentes autorrepresentaciones. El texto de Caggiano (que refiere a otro tipo de fotografías, como las presentes en archivos oficiales) muestra que incluso en clasificaciones más duraderas en el tiempo, las 
categorías también son acomodadas y se establecen correcciones mínimas (aunque significativas) en su ordenamiento. Al respecto, la rectificación que el autor analiza en la categoría recientemente ingresada de "afroamericanos" podría también tener el efecto de desdibujar la inclusión de los negros argentinos en la historia nacional, a partir de un agregado que resulta inespecífico para señalar esta presencia.

En cuanto a las imágenes que en la actualidad circulan fuera del ámbito doméstico, referí a las fotografías utilizadas por organismos del Estado en la campaña de sensibilización sobre la variable de afrodescendencia aplicada en el último censo nacional de población (año 2010) ${ }^{12}$, cuyo contexto y las disputas que lo signaron se encuentra recuperada por Fernández Bravo. Estos pósters y fotografías, utilizados en el marco de una campaña orientada a sensibilizar a la población sobre la presencia de afrodescendientes, se vieron reforzados por el estatus evidencial de las imágenes. Estas fotos, a su vez, fueron pensadas para captar a una población que, aún asumiendo una identidad blanca-europea, podría descubrir algún probable parentesco o ancestro africano o que, conociéndolo, podría llegar a reconocerlo como parte de su identidad personal. En este sentido, quizá por primera vez, la blanquedad sobre la que se proyectan los fotografiados no es completamente invariable, ya que podría ser puesta en entre dicho.

Ahora bien, ¿qué muestran estas fotos? Su foco se centra en los rostros suspendidos sobre un fondo de colores que, al no agregar información sobre los representados, lleva a focalizar la mirada en éstos. Si bien la estrategia fotográfica parece orientada a realzar el efecto individualizador mostrando la heterogeneidad de fenotipos afrodescendientes, parecería también dirigir una mirada conducente a focalizar en ciertos rasgos (no individualizados) que lleven al descubrimiento de un potencial vínculo con la afrodescendencia. La sola referencia a los rostros, corre en algunos casos el riesgo de realzar una rareza que, como señala Fernández Bravo, genera el efecto de extranjerizar a los representados.

57 Interactúa aquí la dimensión realista presente en toda medición censal, con las fotografías que llevan a la determinación visual de estos rostros soslayando otros elementos, como podrían ser los contextos históricos más amplios, altamente efectivos en la construcción de un imaginario blanco-europeo asentado en la desaparición de los afroargentinos. Coincido en que, como señalan Caggiano y Fernández Bravo, esbozar una respuesta a la pregunta sobre cómo representar este proceso de invisibilización a partir de las imágenes resulta un desafío sobre el que aún no hay respuestas sencillas.

Actualmente existe un número significativo de imágenes que participan de un circuito digital ${ }^{13}$ dificultoso de reconstruir (si no imposible), dada su vertiginosa circulación en redes sociales. Un caso que utilizaré a modo de ejemplo lo constituye la actual página de facebook "Docke en la memoria", donde son expuestas fotografías antiguas que retratan con intención evocativa diferentes acontecimientos del pasado de la localidad. En esta página suelen aparecer imágenes sobre las diferentes colectividades que habitaron Dock Sud, entre ellas la caboverdeana. Representados en diferentes actividades como en bares, colegios $^{14} \mathrm{y}$ carnavales, o caminando por el barrio, estas fotos, y otras presentes en archivos más conocidos ${ }^{15}$, parecerían relativizar la idea referida a la ausencia de fotografías de argentino-caboverdeanos, que podría hacerse extensiva a otros afroargentinos ${ }^{16}$. Como señalé en el anterior escrito, el repliegue en el ámbito doméstico generó una aparente ausencia de información documental, entre las que figuran las fotografías, que se torna paradójica ante la presencia de imágenes que, una vez digitalizadas, circulan por la web. 
59

estimar, puesto que en muchos casos se limita a una visibilización superficial y espontánea que no va más allá de la sorpresa ante determinadas presencias "extrañas" cuyos efectos se diseminan rápidamente en el tiempo. Estas imágenes fotográficas ofrecen sin embargo una mirada histórica dinámica, que en la página aludida retrata a argentinocaboverdeanos de diferentes edades compartiendo actividades junto a otros vecinos, complejizando una mirada que invita a pensar en procesos de mestizaje, expresados a partir de una "idea diferente" del crisol de razas que permite que las pieles no blancas se visualicen y reconozcan como parte de la nación (Adamovsky 2013). Asimismo, esta mirada pivotea con una representación que enfatiza en un encuadre migratorio (constante en el tiempo), lo cual nos remite a un modo no menos efectivo de extranjerización, difícil de eludir, dado que en ocasiones este marco continúa siendo apropiado por los miembros de la comunidad para visibilizarse ${ }^{17}$.

61 El tono nostálgico de la página, con fotografías que invitan a evocar un pasado que "ya no volverá" podría interpretarse como el réquiem de una presencia (como la argentinocaboverdeana) que podría seguir el mismo curso. Sin embargo, quienes comentan estas fotos, las comparten en las redes sociales, las "descargan", digitalizan y hacen circular por numerosos espacios son en su mayor parte los mismos protagonistas y sus familiares que aún hoy mantienen activas las instituciones con proyectos y actividades que los continúan convocando.

\section{Reflexiones finales de las editoras sobre el debate}

\section{Eva Lamborghini y Lea Geler}

62 El estudio de imágenes en torno a lo "negro" (en su sentido polisémico, amplio y contradictorio) en Argentina muestra una producción significativa y creciente de investigaciones, pero aún está lejos de conformar un tema consolidado con debates y/o tesis contrapuestas definidas. Sin embargo, advirtiendo una atractiva masa crítica, acaso el posible advenimiento de un "giro visual" en el campo de los estudios afroargentinos y/ o de las categorías y relaciones racializadas en nuestro contexto, nos pareció ésta una oportunidad para realizar un recorrido de lo producido hasta aquí e invitar autores con trabajos e intereses actuales a bucear en las complejas intersecciones entre lo visual y lo racial. Por ello, uno de nuestros objetivos principales fue abrir preguntas y visibilizar vacancias en los análisis, lo que dio por resultado una dinámica de trabajo particular. Nuestro primer horizonte fue poner en diálogo producciones sobre la temática de los autores convocados, cuya primera ronda de textos fue antecedida por preguntas y ejes orientadores que problematizaron y pusieron en relación los amplios conceptos del título: “imágenes racializadas", "políticas de la representación" y "economía visual”. Luego, a partir de la lectura de los textos presentados, organizamos -ahora sí- ejes para el Debate, tanto generales como cruces y conversaciones específicas entre los textos/autores. Un primer conjunto de ejes generales de discusión apuntó a cuestiones metodológico- 
disciplinares relacionadas con la problematización de la mirada del/la investigador/a en la delimitación de lo racial, en juego con la mirada social y con la mirada histórica. Planteamos también los usos de las imágenes como "prueba", lo racial como "verdad" y la (im)posibilidad de "ambigüedad" de las imágenes, así como la necesidad -o no- de lo verbal para explicar las imágenes racializadas y, en sentido extenso, la (no)transparencia de las categorías raciales. Otro conjunto de ejes se dirigió a dirimir sobre los límites o fronteras entre la representación y/o la autorrepresentación en la fotografía/pintura y sobre los cambios -y preguntas- que se producen cuando se mueven esos límites conceptuales. En un tercero indicamos los usos (viejos y nuevos) de las fotografías o imágenes de/con afrodescendientes en la economía visual, y la politización de las imágenes racializadas en distintos contextos históricos y modos de entendimiento de lo "negro" y/o lo afro. Por último, propusimos un eje en torno a la imagen como promesa, como potencial reparador de las desigualdades representacionales y sobre las ventajas, desafíos y problemas al respecto.

Los autores tomaron algunos de estos ejes generales y/o las discusiones específicas y otros, claro, que sus propias búsquedas y lecturas les despertaron. Algunos de ellos optaron también por realizar una síntesis o lectura del conjunto de los textos. Asimismo, casi todos/as incorporaron nuevas imágenes, ya sea fotografías (Ghidoli incluso complementa algunas de las analizadas por Caggiano en la primera instancia) y/o videos (como en el caso de Adamovsky), este último tipo de soporte no incluido en los primeros textos y que claramente toma parte importante en las representaciones racializadas en sus diversas formas. Las nuevas incorporaciones iconográficas, consideramos, no hacen más que confirmar el entusiasmo de todos los involucrados por haber participado de la apertura de este diálogo.

Los temas en común, los enfoques convergentes y divergentes y el arco temporal de los trabajos (desde las primeras décadas del siglo XX hasta la actualidad), que cubre contextos profundamente disímiles no sólo en tanto ideologías de nación sino también en tanto políticas de estado y de gobierno, abrieron un espacio riquísimo para el debate. Si bien la ligera preponderancia de autores miembros del GEALA $^{18}$-al que las editoras también pertenecemos- resultó en un énfasis en lo "afro", los textos exceden los temas y discusiones relativos a este campo específico. Imágenes de "negros", pero también de "indígenas", de "mestizos", de "criollos", de "gauchos", van planteando relaciones y preguntas en torno a cómo, ya sea en el archivo, en la propaganda estatal o en las investigaciones académicas, se entra/sale/se posicionan esas otras alteridades frente a la alteridad "negro/negritud" y frente a lo "blanco/blanquitud". Entonces, la negritud aparece en articulación con lo indígena, el mestizaje, o la dimensión étnico-racial del criollismo, como plantea Adamovsky, la racialización de lo indígena, la etnicización de lo negro, la construcción cultural de lo fenotípico, la racialización de lo cultural, etc. Así como las discusiones entre los autores recuperan las intersecciones y solapamientos entre la negritud racial y la negritud popular (Geler 2016), también capturan las especificidades a la hora de pensar y analizar procesos de visibilización, invisibilización, estereotipación, estigmatización sobre los "negros argentinos" como un colectivo social existente (o "desaparecido", o "desapareciendo", o "aún existente", o "resurgiendo", etc.), o sobre los "negros" como individuos racializados y enclasados pero no necesariamente (auto)identificados como grupo étnico-racial al interior de la nación. Con mayor centralidad en los escritos que expresamente dialogan y debaten en la segunda ronda, las autoras $\mathrm{y}$ los autores esgrimen reflexiones sobre las inclusiones subordinadas $\mathrm{y}$ 
contradictorias, como apunta Martino, de los grupos racialmente marcados, luego desmarcados, etc., en el estado-nación, reparando en cómo estos procesos se vuelven comprensibles y atendiendo a los distintos lugares asignados en la formación nacional de alteridad argentina en función de racializaciones y etnicizaciones diversas (Briones 2005; Segato 2007).

Además del predominio -aunque no exclusividad- de lo "afro", otro énfasis resultante de esta convocatoria es una mirada que parte de y se centra en Buenos Aires. Por ello, asumimos como pendiente la necesidad de ampliar los ejes de discusión a otras zonas del país, lo que necesariamente redundará en nuevos temas de debate y en nuevo conocimiento. De este modo si, como pensamos, vale la pena preguntarse por la posibilidad y los desafíos de avanzar sobre el análisis de la Argentina no-blanca a partir de un estudio integrado y sistemático que tenga la producción visual como uno de sus aspectos articuladores, este desafío requiere tanto el diálogo entre los análisis que tematizan estas cuestiones como el trabajo desde niveles locales y regionales, todo lo cual ayudará a componer y descomponer, sin dudas, la visión de fondo del caleidoscopio nacional.

Antes de continuar, queremos dejar sentadas muy sintéticamente algunas ideas axiales que aunque evidentes para muchos no dejan de sorprender a otros: la división moderna de la humanidad en razas es una invención social que tiene un origen específico (el siglo XIX y el imperialismo europeo), una historia (la conquista de América, la trata esclavista negro-africana y concepciones raciales pre-modernas que se fueron enquistando en un sistema-mundo capitalista con un centro y una periferia, con fuerzas de trabajo diferenciadas ${ }^{19}$ ) y una forma de explicación que la hace parecer lógica (la "ciencia" positiva que servía a los fines imperialistas). El ordenamiento social resultante de la división racial es reproducido hasta hoy en día en base a ideas que surcan el mundo occidental (la más importante aquí sería la superioridad de la raza blanca) y se conjugan con ideas locales a través de las cuales se arraigan. Efectivamente, la forma en que se delinean lo blanco y los otros colores varía según la época y el lugar, y su fijación en patrones culturales y en culturas visuales, como marca Caggiano, requiere una gran cuota de esfuerzo y de coacciones pero, como en todo proceso de hegemonía, también de consensos, de negociaciones, de producción y de reproducción social, temas abordados por todos los autores del Debate.

Como marcamos en la Introducción, en la Argentina la negritud racial porteña ha quedado reducida a unas constantes visuales corporales muy específicas. Sin embargo, la racialización es una práctica que excede lo negro y lo blanco -como bien señala Caggiano en el Debate- que juega con las ideas raciales de manera ambigua y lábil, engañosamente, pero que sigue enquistada en su mayor parte en el ámbito visual. Es así que tanto como es engañoso pensar que "en Argentina no hay negros" -llevando a que toda persona vista como negra sea considerada extranjera-, también es engañoso suponer que cuando vemos "ancestros" indígenas en los cuerpos, o cuando llamamos a alguien "negro cabeza" o "negro de alma" según una "forma de ser" que se visualiza -aunque sea mentalmentecomo "no adecuada" (en relación con otra que se percibe como adecuada), no estamos usando concepciones racializadas. Porque la negritud popular, como también señalamos en la Introducción, es una forma profundamente racializada de entender nuestra realidad circundante, si bien intervenida de manera constante por categorizaciones de clase y de género que la anudan en el lenguaje y, especialmente, en el plano visual, que es el que nos atañe aquí. Por eso, acordamos con Caggiano en que no son sólo los cuerpos los que 
hablan de racializaciones, pero sí invocamos a la dimensión visual como un plano inextricable de los procesos de racialización en la actualidad, siempre en relación con las formas locales de los mismos.

68 Las imágenes sobre/con/de afroargentinos no son pocas. Carecen, por un lado, de sistematización, como señala Martino, y, por el otro, de posibilidad de circulación pública masiva, como muestran Martino y Fernández Bravo. En el primer caso, el ámbito ideal para realizar aquel ordenamiento sería el Archivo General de la Nación en su Departamento de Documentos Fotográficos (DDF). Explica Caggiano que lo que en realidad allí sucede es la construcción continuada de una ausencia que, según este autor, Ghidoli y Martino, prolonga la imposibilidad negra en el país, hoy realizada a través de la utilización de categorizaciones inespecíficas ("afroamericanos"). Si lo afroargentino fue construido visualmente como ausente -creando la idea de "ausencia ausente" expresada por Fernández Bravo, que queda desafiada por la presencia misma de imágenes de afroargentinos de todas las épocas y lugares- y se procedió a la no sistematización y no archivización de sus imágenes, esa construcción visual de ausencia (pero también la de presencia, en los pocos casos en que aparecen los afrodescendientes como tales en las imágenes locales) siempre requirió -como puntualizan Ghidoli y Caggiano- de lo verbal para acompañarla. Los textos demuestran el problema de la dispersión y, sobre todo, del contexto o bien, la descontextualización en el sentido de Ghidoli, de los discursos con las que dichas imágenes aparecen asociadas. Este es uno de los puntos destacados en el Debate que ilumina cómo aspectos teóricos relativos al estudio de las imágenes en general, como el discernimiento de la imbricación entre las imágenes y el lenguaje verbal (la palabra), se redimensionan al abordar representaciones racializadas en nuestro contexto, ya sea entendiendo el segundo en tanto discursos, ideologías, narrativas dominantes, imaginarios (o sea, en un sentido amplio), o en tanto lenguaje verbal textual escrito, o lenguaje verbal oral (como en los usos que contextualiza Martino). Líneas de debate particulares se abren en torno a la potencialidad (o bien la pregunta sobre lo adecuado) de plantear la imagen más allá de lo verbal y sobre qué nos puede decir la existencia per se de imágenes de afroargentinos, y/o de personas no-blancas.

69 Sin embargo, en líneas generales no vemos esas imágenes. La invisibilización coexiste cono, según Ghidoli, es resultado de- la estereotipación, extranjerización y exotización del colectivo social afroargentino. Igualmente, de forma paradójica muchas veces coexiste con la hipervisibilidad, que termina erosionando lo afroargentino de lo visible. Por eso, la idea que presenta Caggiano de la invisualización nos parece absolutamente pertinente aquí, en tanto una "pedagogía de la mirada" continuada. En primer lugar, podemos pensar que el discurso de la blanquitud ha moldeado de tal manera nuestras formas de ver que no podemos todavía superar el manto que vela toda forma de no-blanquitud de las imágenes. En segundo lugar, debemos tener en cuenta los "microprocesos sociales" propuestos por Frigerio (2006) en los que esas personas que no desean verse incluidas en un colectivo racial o étnicamente marcado usan estas imágenes para sus propios fines, como muestra uno de los casos del artículo de Martino $^{20}$. Pero, en tercer lugar, hay que sopesar la posibilidad de que la canalización de la diversidad étnico-racial a través de la estructura de clases y la conformación de la negritud popular haya sido uno de los modos más efectivos de construir esa ceguera. Y nos referimos por ceguera no sólo a que no se pueda ver "un negro" (en tanto argentino) en una imagen, sino especialmente a que se piense que, porque no se diferencian razas, asumiendo en ella a todas las personas como blancas, no estamos usando una mirada tan profundamente racializada como aquella que 
ve razas distintas en todas partes y que es característica de otras formaciones nacionales de alteridad, como las anglosajonas. Por eso interesa ver lo no-blanco de las representaciones visuales de lo criollo/gauchesco agudamente analizadas por Adamovsky, aunque sea muy probablemente en clave "mestizo del interior" o "descendiente de indígena", incluso con una mirada más actual, "migrante latinoamericano", abriendo inmediatamente una cadena semántica que une pobreza, ruralidad, falta de educación (urbano-europea). Pero hay que recalcar que en ese contexto, como muestra Ghidoli, cuando se presentan afroargentinos (como en los casos de presintificación visual de afroargentinos que plantea Adamovsky) se hace de un modo "no directo" (ámbitos teatralizados, ambiguos, etc.) incluso de manera "falsa" (blancos tiznados), volviéndolos una ausencia, tal y como marcan Caggiano y Ghidoli. Lo mismo sucede con el rótulo "afroamericanos" del Archivo General de la Nación, según lo señalado por Caggiano, Martino, Ghidoli y Fernández Bravo. Así, cuando Caggiano retoma el tema que gira en torno a la "necesidad" de tizne para representar cuerpos negros, debemos tener en cuenta que la negritud racial, en definitiva, se enraíza en la visualidad de un color de piel (por supuesto, según percepciones de colores cultural e históricamente codificadas) pero también en la idea de que no hay negros argentinos que puedan usar sus cuerpos para autorrepresentarse ${ }^{21}$. En este punto, el blackface local difiere del Jim Crow estadounidense, si bien se retoman muchos de sus elementos, como lo expone Ghidoli.

70 A la apropiación "corporal-visual" que supone la práctica del tizne, tema álgido si los hay, la "apropiación cultural" más allá de la idea de canibalización o de la mera "explotación", en los términos de Adamovsky, aparece también en esta segunda ronda y renueva el énfasis en la dificultad teórica y política -doblemente compleja en un análisis de lo visual- a la hora de referirnos no sólo a grupos socialmente negros sino también a los "blancos", o los múltiples embrollos que resultan cuando quiere hacerse referencia a sectores no categorizados ni en la negritud racial ni en la negritud popular, en un país en el que se ha negado históricamente la existencia de grupos étnico o racialmente diferenciados.

71 Lo que el artículo de Adamovsky también recuerda es que poner de relevancia la marcación "racial" o la heterogeneidad étnico-racial presente en diversas imágenes, no necesariamente sobre afros o sobre pueblos indígenas, ayuda a visualizar cómo las imágenes oficiales de la nación argentina blanca-europea, aunque dominantes, son también disputadas de (distintas) maneras, -más o menos abiertas o explícitas como argumenta el autor-, algo que invita a volver a mirar las imágenes del pasado y del presente en esa clave. Y aquí sería interesante pensar, retomando la idea de la negritud racial canalizada en la popular, cómo la conformación actual de la negritud popular abre la posibilidad no sólo de la creación de una identidad de orgullo (Frigerio, 2009; Adamovsky, 2012), sino también de la conformación de nuevas vías racializadas de explorar lo no blanco y de hacerlo posible, de abrirle un acceso a la esfera pública más "admisible" que la sola presencia de pueblos indígenas y de afroargentinos en el país de una manera no estereotipada y exotizante. Esto se relaciona, por un lado, con el punto planteado anteriormente de la privatización de las imágenes (su encierro en el ámbito doméstico) o de ver su camino hacia la esfera pública truncado. Justamente, Fernández Bravo enfatiza en el "uso político de la identidad visual" y en la problematización de los contextos públicos y privados de circulación de las imágenes, en donde las fotos familiares domésticas, privadas, aparecen asociadas a la autonomía de las relaciones 
coloniales en las que, el autor considera, aún se encuentran situadas las políticas de la representación. Aquí nuevamente la idea de invisualización se torna fecunda, en tanto esa pedagogía de la mirada enseña también a desestimar como no importantes, o como espurios, los rastros que puedan poner en duda la blanquitud. Por el otro, con las formas que adquieren hoy día las marcaciones de diferencia, que se suman a las demandas planteadas por afrodescendientes en Argentina y los pueblos indígenas, entre otros colectivos que sufren discriminación y desigualdad.

Esto nos lleva nuevamente a uno de los temas más densos que se plantearon en el debate: el de la representación y la autorrepresentación. Si, como dice Ghidoli, toda imagen de afroargentinos o afrodescendientes (incluso si están allí como personas únicas) no refiere a un individuo sino a un colectivo, está sugiriendo que no sucede lo mismo con los "blancos" (¿o sí, pero la blanquitud continua construyéndose como invisible?). Evidentemente esto tiene relación con la forma en que la nación ha construido sus alteridades y sus mismidades, y qué es lo que se resalta visualmente a partir de determinadas matrices culturales (la cultura visual). Justamente, en la cultura visual argentina lo afro, lo indígena, lo rural, lo pobre, lo no europeo todavía aparece como una alteridad, mientras lo blanco europeo "no se ve", permanece invisible.

Entonces, si toda imagen de afro refiere a un colectivo, puede ser apropiada como forma o prueba de identidad personal en relación a un colectivo o de un colectivo en relación con otro, volviéndola de autorrepresentación, una idea también señalada por Fernández Bravo. Esta forma de pensar la autorrepresentación de la imagen anclada en los usos, apropiaciones y no en una decisión, una autoría, o en si la persona está presente allí tema expuesto por Martino y por Fernández Bravo- es interesante para revisar algunos de los supuestos de trabajo sobre representaciones racializadas, especialmente en relación con la economía visual y con las políticas de la representación.

74 Ahora bien. Es imprescindible, como enfatiza Ghidoli, que al momento de analizar las imágenes seamos capaces de contextualizarlas. Pero, ¿qué nos implica como investigadores entender que una imagen cuyo contexto de producción conocemos -por ejemplo, una imagen creada para remarcar la pobreza urbana y la desaparición afro de principios de siglo- está hoy en día siendo usada como forma de autorrepresentación afro? ¿Cómo y en qué circunstancias debemos reponer el sentido histórico original? ¿Cómo debemos negociar con los usos que los miembros de comunidades subalternizadas y negadas por centurias les dan a esas imágenes, y que además tienen la posibilidad hoy día de cruzar las fronteras de lo doméstico a través del uso digital y virtual de las mismas, como señala Martino? Un ejemplo contundente en este sentido lo presenta Ghidoli. Juan, afroargentino, le muestra a la autora una imagen de afroargentinos del pasado, con la intención de trazar la historia, su historia, como un continuum con ella. Esa imagen, sin embargo, había sido publicada originalmente para mostrar la desaparición afro del país. Más aún. Para Juan, su propio cuerpo marcaba la presencia actual de los afroargentinos. Sin embargo, comúnmente hasta el día de hoy la presencia de los afroargentinos no marca pertenencia nacional sino, por el contrario, extranjería y exotismo.

Porque la negritud racial sólo permite ver exotismos, extranjerías, hipersexualización y un pasado nacional remoto. En este sentido, podemos agregar que la invisualización tiene un componente histórico fundamental ya que permite leer las imágenes asociadas a “épocas", e implica el proceso por el que hay que recurrir a imágenes de la colonia o del siglo XIX para mostrar visualmente la negritud (racial) argentina. Por el contrario, la negritud argentina es posible en tanto popular, que en la mayoría de los casos parece 
tornarse un producto nacional típico, en tanto también dialoga con versiones internacionales que unen pobreza y negritud (rap, cumbia, tipos de vestimenta, etc.), temas que quedan abiertos a la profundización.

Es por esto que invenciones como Obaca (no mencionada en los textos pero que los sobrevuela de forma ineludible), el falso candidato negro a la presidencia argentina que invadió con su cartelería la vía pública y con sus videos la Internet durante la campaña electoral del año $2015^{22}$ y continúa vigente, pueden ser más pervasivas que mil escritos: porque a la mera visualidad de la negritud racial se le necesitan agregar discursos verbales y escritos, o marcaciones auditivas (habla porteña), que enfaticen lo nativo y que encaucen en lo comprensible lo que se ve, algo que en general se realiza a través de lo ridículo/risible (en relación con lo imposible en este caso) y que corre el peligro de traer a la masividad pública nuevamente los señalamientos del grotesco, como indica Ghidoli. Pero siempre, en todo caso, son elementos que nos afectan, algo que debemos tener en cuenta porque estamos frente a materiales que comunican desde planos simultáneos y diversos, casi nunca actuando solos para construir lo racial que, invención también, se deshace si no se lo apuntala desde múltiples espacios.

Como puede advertirse a lo largo de estas últimas páginas del Debate, en cada texto en particular y en su lectura en conjunto se presentan planteos y preguntas muy lúcidas de no fácil resolución que abren más que cierran las reflexiones e investigaciones sobre las categorizaciones raciales en su retroalimentación compleja y no lineal con lo visual, las representaciones estatales (hoy más multiculturalistas) de la diversidad étnico-racial y lo nacional argentino, la representación y la autorrepresentación en relación mutua, la politización del uso de las imágenes, su circulación pública y privada (también en relación), entre muchas otras dimensiones. La profundidad y relevancia de los textos confirman que el debate está ahora abierto, pudiendo tomar de aquí en adelante diversos ejes, énfasis y alcances. Por todo lo dicho, agradecemos a cada uno de los autores por su interés y compromiso e invitamos entusiastamente a continuar el debate en números sucesivos.

\section{BIBLIOGRAPHY}

Adamovsky, E. (2013). La dimensión étnico-racial de las identidades de clase en la Argentina. El caso de Cipriano Reyes y una hipótesis sobre la "negritud" no diaspórica. En F. Guzmán y L. Geler (Eds.) Cartografías afrolatinoamericanas. Perspectivas situadas para análisis transfronterizos. (pp. 87-112). Buenos Aires: Biblos.

Adamovsky, E. (2012). El color de la nación argentina. Conflictos y negociaciones por la definición de un ethnos nacional, de la crisis al Bicentenario. Jahrbuch für Geschichte Lateinamerikas 49:343-364.

Andrews, G.R. (1989). Los Afroargentinos de Buenos Aires. Buenos Aires: De La Flor.

Gordillo, G. (2006). En el Gran Chaco. Antropologías e historias. Buenos Aires: Prometeo. 
Arias, J. y Restrepo, E. (2010). Historizando raza: propuestas conceptuales y metodológicas. Crítica y Emancipación, (3), 45-64.

Berger, J. ([1974] 2005). Modos de ver. Barcelona: Gustavo Gili.

Briones, C. (2005). Formaciones de alteridad: contextos globales, procesos nacionales y provinciales. En C. Briones (Ed.). Cartografías Argentinas. Políticas indigenistas y formaciones provinciales de alteridad. pp.11-43. Buenos Aires: Antropofagia.

Burucúa, J. E., Malosetti Costa, L. (2012). Una palabra equivale a mil imágenes. Polisemia, grandeza y miserias de las representaciones visuales. Concreta, (00), 6-13.

Caggiano, S. (2012). El sentido común visual. Disputas en torno a género, "raza" y clase en imágenes de circulación pública. Buenos Aires: Miño y Dávila editores.

Chartier, R. (1990). La historia cultural redefinida: prácticas, representaciones, apropiaciones. Punto de Vista, (39), 43-48.

De la Cadena, M. (2008). Formaciones de indianidad. Articulaciones raciales, mestizaje y nación en América Latina. Lima: Envión editores.

Didi Huberman, G. (2012 [2007]). El archivo arde (Das Archiv brennt). Didi-Huberman, G. y Ebeling, K. (eds.). Das Archiv brennt. (p. 7-32). Berlin: Kadmos. Traducción de Juan Ennis. Disponible en: http://filologiaunlp.wordpress.com/bibliografia/

Geler, L. (2010). Andares negros, caminos blancos. Afroporteños, Estado y Nación Argentina a fines del siglo XIX. Rosario: Prohistoria/TEIAA.

Geler, L. (2011). ‘¿Quién no ha sido negro en su vida?’ Performances de negritud en el carnaval porteño de fines del siglo XIX e inicios del XX. En P. García Jordán (Ed.). El Estado en América Latina: control de los recursos, organización sociopolítica e imaginarios, siglos XIX-XXI. (pp.183-211). Barcelona: PiEUB.

Geler, L. (2013). Afrodescendencia y mundo urbano popular en Buenos Aires (1895-1916): el caso de Zenón Rolón y Chin Yonk. En P. García Jordán (Ed.). La articulación del Estado en América Latina. (pp:207-226). Barcelona: PiUB.

Geler, L. (2016). Categorías raciales en Buenos Aires. Negritud, blanquitud, afrodescendencia y mestizaje en la blanca ciudad capital. Runa. Archivo para las ciencias del hombre, 37(1):71-87.

Ghidoli, M. (2016). Estereotipos en negro. Representaciones y autorrepresentaciones de afroporteños en el siglo XIX. Rosario: Prohistoria.

Goldberg, M. (2000). Las afroargentinas (1750-1880). En F. Gil Lozano, V.S. Pita y M. G. Ini (Dirs.) Historia de las mujeres en la Argentina, Tomo 1. Buenos Aires: Taurus. pp. 66- 85.

Frigerio, A. (2006). “Negros” y “Blancos” en Buenos Aires: Repensando nuestras categorías raciales. En L. Maronese (comp.). Buenos Aires Negra: Identidad y Cultura. (pp.77-98). Buenos Aires: CPPHC.

Frigerio, A. (2009). Luis D’Elia y los negros: identificaciones raciales y de clase en sectores populares. Claroscuro. Revista del CEDCU de la UNR, 8:13-44.

Gomes da Cunha, O. (2002). Intenção e Gesto: pessoa, cor e a produção catidiana da (in)diferença no Rio de Janeiro, 1927-1942. Río de Janeiro: Arquivo Nacional.

Marin, L. (2009 [1981]). Poder, representación, imagen. Prismas, (13), 135-153.

Peirce, Ch. S. (1967 [1933]). Collected Papers of Ch. S. Peirce. Cambridge: The Belknap Press of Harvard University Press. 
Poole, D. (2000). Visión, raza y modernidad. Una economía visual del mundo andino de imágenes. Lima: Sur Casa de Estudios del Socialismo y Consejería en Proyectos.

Salvatore, R. (2003). Wandering Paysanos: State Order and Subaltern Experience in Buenos Aires during the Rosas Era. New Carolina: Duke University Press.

Segato, R. (2007). La Nación y sus Otros. Raza, etnicidad y diversidad religiosa en tiempos de Políticas de la Identidad. Buenos Aires: Prometeo.

Tell, V. (2011). Sitios de cruce: lo público y lo privado en imágenes y colecciones fotográficas de fines del siglo XIX. En M. Baldasarre y S. Dolinko (Eds.). Travesías de la imagen. Historias de las artes visuales en la Argentina Vol. 1. (pp. 209-233). Buenos Aires: Eduntref-CAIA.

Wallerstein, I. (1991). La unidad doméstica y la formación de la fuerza de trabajo en la economíamundo capitalista. En E. Balibar. y I. Wallerstein Raza, Nación y Clase. (pp. 169-178). Madrid:

IEPALA.

\section{NOTES}

1. https://www.youtube.com/watch?v=Us1aPHvgtLc

2. https://www.youtube.com/watch?v=mfmuIAnz7-4

3. https://www.youtube.com/watch?v=MAbQpMkKH6g

4. Vemos semejanzas (y -o porque- vemos diferencias), vemos fragmentos de un contexto mayor y vemos valores asociados a lo que vemos, o sea, vemos el color de piel como ícono, como índice y como símbolo (Peirce 1967 [1933]).

5. Cabe también recordar que otros trabajos históricos han mostrado la importancia de la apariencia en la conformación de las disputas de clase de mediados del siglo XIX en Argentina (Salvatore 2003), e incluso el vínculo que las apariencias, la posición social y la "pureza de sangre" tenían en el contexto colonial tardío (Goldberg 2000).

6. Con "visibilización" aludo a una puesta en agenda y un reconocimiento que articulan lenguajes heterogéneos, entre los que tiene gran relevancia la palabra oral y escrita, y reservo "visualización" para referir particularmente al uso de imágenes.

7. La nota fue reproducida de manera completa por Alejandro Frigerio en el blog Afroamericanas http://alejandrofrigerio.blogspot.com.ar/2012/07/el-patrimonio-de-la-nacion-camunda-en.html

8. Las naciones eran un tipo de asociación afroargentina creada a partir de lo establecido por un reglamento policial de principios de la década de 1820 y cuya finalidad principal declarada era la obtención de fondos para la manumisión de los esclavizados. Era habitual que sus miembros compraran el lote en el cual se asentaban los sitios de nación y estas sedes se ubicaban en gran parte en el actual barrio de Monserrat.

9. En Cabo Verde la ciudadanía y el pasaporte fueron un potente símbolo del distanciamiento de la africanidad. Este punto nos acerca a la dimensión ceremonial y emotiva -referida al reconocimiento oficial- que otorgan los documentos. Como señala Gordillo para los Tobas del oeste formoseño, el valor que las personas dan a éstos ilumina "[una] subjetividad producida por la incorporación contradictoria en el estado-nación argentino" (2006, p.169) que se encuentra también presente entre los afroargentinos porteños aunque de manera diferente. Entre las personas con las que trabajé, fue usual el acercamiento de documentos de Cabo Verde y Argentina, o de certificados expedidos por compañías navieras del Estado que expresaban a mi entender una valoración de los simbolismos estatales que evidencian su contribución a la soberanía y al desarrollo nacional, a pesar de que ésta no ha sido reconocida desde un espacio de particularidad identitaria. A pesar de ello, la existencia de documentos muestran lo efectivas que fueron las políticas de ciudadanización entre los inmigrantes durante este periodo, y a su vez 
marca notorias diferencias con los pueblos originarios que fueron privados de esta documentación durante décadas (Gordillo 2006).

10. Adamovsky refiere a la redefinición, a fines de siglo XIX y principios de siglo XX, de uno de los discursos fundacionales de la nación argentina, el criollismo, cuando comenzó a enfatizarse la afiliación española del criollo, lo cual a pesar de ello, no anuló las afiliaciones previas, cuya heterogeneidad étnico-racial se afirmó con fuerza décadas después.

11. Las fotografías se han publicado con la autorización de sus propietarios.

12. Colaboré en las actividades de sensibilización llevadas a cabo junto a la Sociedad caboverdeana de Dock Sud. Algunas de las reflexiones presentadas en este escrito se hicieron particularmente presentes durante este período.

13. En la actualidad hemos comenzado a digitalizar, junto a la asociación caboverdeana de Dock Sud, numerosas fotografías con el objetivo de organizarlas y reunirlas. Algunas de estas (especialmente las que refieren al período de la independencia de Cabo Verde) son utilizadas en conmemoraciones, documentales y video-homenajes, ayudando a complejizar la memoria sobre este proceso.

14. Las fotografías en contextos escolares resultan significativas para analizar las trayectorias educativas entre los descendientes en diferentes períodos, ya que permiten observar de manera elocuente cómo se materializó el ideal de la blanquedad en la escuela pública. En particular, el marcado contraste visualizado entre el color blanco-almidonado de los guardapolvos -sus asociaciones de sentido con ideas de "homogeneidad" "pureza" e "inocencia" infantil, entre otras- y las tonalidades cobrizas de piel de algunos que lo vestían, debió haber constituido (probablemente lo siga siendo) una temprana y violenta experiencia de marcación entre los niños y niñas que se insertaban por primera vez en el sistema escolar.

15. Como las fotografías que comparte el Archivo General de la Nación (AGN) en la web, con gran cantidad de seguidores, donde se difunden no pocas fotografías de afroargentinos.

16. Sí existe una ausencia de sistematización de estas imágenes.

17. Esta apropiación debería comprenderse en relación a las políticas que en las últimas décadas han apelado fuertemente a la narrativa migratoria $\mathrm{y}$, especialmente en los últimos años a la metáfora del crisol de razas. (europeo).

18. Grupo de Estudios Afrolatinoamericanos del Instituto de Historia Argentina y Americana "Dr. Emilio Ravignani" de la Facultad de Filosofía y Letras, Universidad de Buenos Aires.

19. Ver Wallerstein (1991).

20. Otro ejemplo es el rompimiento de fotografías de ancestros afro, impidiendo la continuación generacional de un conocimiento y una memoria familiar (Geler 2016).

21. También se puede sugerir en ese contexto que la performance de negro lo que hace es fortalecer la blanquitud de los performers (Geler 2011).

22. Ver https://www.fwtv.tv/obaca (noviembre de 2016). 